\title{
Quantitative Proteomic Analysis of Cervical Cancer Tissues Identifies Proteins Associated With Cancer Progression
}

\author{
ALBERTO RAMÍREZ-TORRES ${ }^{1}$, JEOVANIS GIL ${ }^{1,2}$, SANDRA CONTRERAS ${ }^{1}$, GRACIELA RAMÍREZ ${ }^{3}$, \\ HERIBERTO A. VALENCIA-GONZÁLEZ ${ }^{3}$, EMMANUEL SALAZAR-BUSTAMANTE ${ }^{1}$, LEOPOLDO GÓMEZ- \\ CAUDILLO $^{1}$, ALEJANDRO GARCÍA-CARRANCA $^{3}$ and SERGIO ENCARNACIÓN-GUEVARA ${ }^{1}$ \\ ${ }^{1}$ Proteomics, Center for Genomic Sciences, The National Autonomous \\ University of Mexico (UNAM), Cuernavaca, Mexico; \\ ${ }^{2}$ Division of Oncology, Section for Clinical Chemistry, \\ Department of Translational Medicine, Lund University, Lund, Sweden; \\ ${ }^{3}$ The National Institute of Cancerology (INCan), Mexico City, Mexico
}

\begin{abstract}
Background/Aim: To date, several proteomics studies in cervical cancer (CC) have focused mainly on squamous cervical cancer (SCC). Our study aimed to discover and clarify differences in SCC and CAD that may provide valuable information for the identification of proteins involved in tumor progression, in CC as a whole, or specific for SCC or CAD. Materials and Methods: Total protein extracts from 15 individual samples corresponding to 5 different CC tissue types were compared with a non-cancerous control group using bidimensional liquid chromatography-mass spectrometry (2D $L C-M S / M S)$, isobaric tags for relative and absolute quantitation (ITRAQ), principal component analysis (PCA) and gene set enrichment analysis (GSEA). Results: A total of 622 statistically significant different proteins were detected. Exocytosis-related proteins were the most over-represented, accounting for $25 \%$ of the identified and quantified proteins. Based on the experimental results, reticulocalbin 3 (RCN3) and Ras-related protein Rab-14 (RAB14) were chosen for further downstream in vitro and vivo analyses. RCN3 was overexpressed in all CC tissues compared to the control and $R A B 14$ was overexpressed in squamous cervical cancer (SCC) compared to invasive cervical adenocarcinoma (CAD). In the tumor xenograft experiment, RAB14 protein expression was positively correlated with increased tumor size. In addition,
\end{abstract}

This article is freely accessible online.

Correspondence to: Sergio Encarnación-Guevara, Centro de Ciencias Genómicas, Universidad Nacional Autónoma de México, Av. Universidad s/n, Col. Chamilpa, Cuernavaca 62210, México. Tel: +55 7773291899, Fax:+55 7773175094, e-mail: encarnac@ccg.unam.mx

Key Words: RAB14, RCN3, cervical adenocarcinoma, exosome, ITRAQ, proteomics.
RCN3-expressing HeLa cells induced a discrete size increment compared to control, at day 47 after inoculation. Conclusion: RAB14 and RCN3 are suggested as potential biomarkers and therapeutic targets in the treatment of $C C$.

Cervical cancer (CC) is the fourth most frequently diagnosed cancer in women, with an estimated 265,000 deaths worldwide (1). A large majority (around $80 \%$ ) of the global burden occurs in the less developed countries (2). Careful retrospective investigations have strongly implicated highrisk human papillomavirus (HPV) with cervical carcinogenesis (3). Although CC diagnosis and treatment programs have decreased the number of cases and mortality rates, the prognosis and complete response to treatment remain poor in CC variants $(4,5)$. Approximately $80 \%$ of the $\mathrm{CC}$ cases worldwide are of the squamous cervical cancer (SCC) type, with the remainder being invasive cervical adenocarcinoma (CAD) (6). The incidence of CAD has increased, especially in younger women (7). During the last two decades, the relationship between CAD and SCC and all $\mathrm{CCs}$ has doubled even in developed countries. This epidemiological evidence suggests that current screening practices are inadequate to identify a significant proportion of CAD precursor lesions (8).

In a population-based study in Korean women, it was shown that the prevalence of HPV in CAD tissue is approximately $90 \%$ (9). The infection of HPV 16 and/or HPV 18 accounted for $78 \%$ of HPV-positive CADs, and multiple HPV types were found in the remaining $13 \%$ of cases (9). Risk factors for developing CC that have been described in SCC include the use of oral contraceptives for more than five years, smoking, and HPV infection (10). However, nowadays HPV infection is fully accepted as the common trigger factor for SCC and CAD development (11). Considering the high morbidity of the disease and the poor 
prognosis of CC types, it is essential to identify proteins involved in CC development.

Isobaric tags for relative and absolute quantitation (ITRAQ) combined with two-dimensional liquid chromatography (2D LC-MS/MS), are among the most powerful methodologies in quantitative proteomics. The multiplexing scope offered by ITRAQ reagents allowed us to identify and quantify changes in protein expression in $\mathrm{CC}$ tissues ( $\mathrm{SCC}$ and $\mathrm{CAD}$ ), enabling comparison between them, and of each of them against normal cervix tissue (NCT) used as control. Consequently, proteomics is a useful tool to classify cells and tissues from pathological conditions and understand different biological mechanisms (12).

In this study we used a mass spectrometry-based quantitative proteomics approach to obtain proteomic profiles of SCC and $\mathrm{CAD}$ to achieve an integrated analysis by principal component analysis (PCA) and gene set enrichment analysis (GSEA) of differentially expressed proteins. Our analysis revealed several proteins up-regulated in both conditions in comparison to the control. Reticulocalbin 3 (RCN3) and Ras-related protein Rab14 (RAB14) were selected for further analysis. HeLa cells overexpressing RAB14 and RCN3 separately were inoculated in nu/nu mice to elucidate RCN3 and RAB14 roles in CC. Our data indicated the fundamental role of these proteins in the regulation and progression of CC cells.

\section{Materials and Methods}

Samples and reagents. We analyzed $15 \mathrm{CC}$ tissue samples from patients (mean age $=45.5$ years, $\mathrm{SD}=12.43$ ) undergoing curative surgery at the Department of Gynecology of the Instituto Nacional de Cancerologia (INCan), Mexico City, Mexico. Normal cervix tissues (NCTs) with no evidence of CC and HPV infection were collected from patients attending the Gynecology Department of INCan, for treatment of cervix benign diseases. All the samples were collected with the consent of the patients and the protocol was approved by the Human Ethics Committee of the National Cancer Institute (INCan). After excision, the tissues were flash-frozen in liquid nitrogen and stored at $-80^{\circ} \mathrm{C}$ until later use. A representative part of the tumor area was collected in $10 \%$ formalin and embedded in paraffin for histopathological analysis. The clinical and pathological data were recorded on a predesigned form, which included the clinical stage of the tumor, histopathological classification, histopathological differentiation degree, HPV type, and age of the patient. HPV detection was performed by PCR analysis by extracting total DNA from $200 \mathrm{mg}$ of CC tissue samples. DNA isolation was performed using a Wizard Genomic DNA purification Kit (A1120, Promega, Madison, WI, USA). DNA concentration was determined using a NanoDrop 2000/c spectrophotometer (Thermo Fisher Scientific, Waltham, MA, USA) and visualized on agarose gel. One hundred $\mu \mathrm{g}$ of total DNA from each CC tumor sample was used as a template to detect HPV by PCR using MY09-MY11 HPV primers, designed to amplify a 450base pair (bp) PCR product (PCRp) from DNA flanking the L1 HPV gene. Amplification was verified by running $10 \mu \mathrm{l}$ of PCRp sample (out of a total PCR reaction volume of $20 \mu \mathrm{l}$ ) on a $1 \%$ agarose gel and staining with ethidium bromide $(0.5 \mu \mathrm{g} / \mathrm{ml})$. A second set of primers targeting the HPV 18-LCR (618-bp) and HPV 16-E6 (544-bp) regions was used for detecting the two most prevalent high-risk HPV types (HPV 16 and HPV 18), and HPV31 was detected using MY09-MY11 (11). PCRps were isolated with the GeneJET purification kit (K0701, Thermo Fisher Scientific) according to manufacturer's protocol and sequenced by capillary electrophoresis. The DNA sequences were analyzed by the Basic Local Alignment Search Tool (BLAST) at National Center for Biotechnology Information (NCBI). The $\beta$-globin housekeeping gene (540 bp) served as a PCR internal control.

The histological diagnosis of each sample was reconfirmed by microscopic examination of a frozen section stained with hematoxylin and eosin (H\&E). Two different pathologists performed a histopathological classification according to the Bethesda System (TBS) to confirm cervical vaginal cytologic diagnoses (13). Next, a representative histological section of the tumor was washed 3

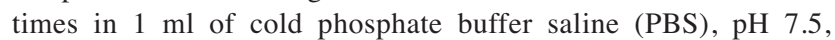
supplemented with protease inhibitors. Frozen samples were crushed and finely homogenized using a handheld homogenizer. Each sample was dissolved in 2 volumes of lysis buffer containing $2 \mathrm{M}$ guanidinium chloride $(\mathrm{GdmCl})$, DNase/RNase, and protease inhibitors for $30 \mathrm{~min}$ at $4^{\circ} \mathrm{C}$. After sonicating three times for $10 \mathrm{~s}$, the samples were centrifuged at $18,000 \times g$ for $5 \mathrm{~min}$ at $4^{\circ} \mathrm{C}$. The supernatant was taken for quantitative proteomics analysis, and the protein concentration was determined by the Bradford method (14). Also, each of 6 groups consisted of 3 individual samples, and all 18 samples were analyzed by SDS-polyacrylamide gel electrophoresis (SDS-PAGE) to confirm sample integrity (data not shown).

Protein digestion and ITRAQ labeling. Protein digestion and ITRAQ labeling were performed as follows. Six pools, each containing 100 $\mu \mathrm{g}$ of protein from three different tumor protein samples, were precipitated with 9 volumes of cold ethanol at $-20^{\circ} \mathrm{C}$ overnight. The pellet was washed 3 times with cold $90 \%$ ethanol. The precipitated proteins were solubilized in $0.5 \%$ sodium dodecyl sulfate (SDS) buffer, $0.1 \mathrm{M}$ triethylammonium bicarbonate (TEAB), pH 8.0. For protein digestion, trypsin was added in a 1:50 ratio (enzymesubstrate), and the samples were incubated for $16 \mathrm{~h}$ at $37^{\circ} \mathrm{C}$. SDS was removed by ethyl acetate extraction under acidic conditions ( 1 volume of ethyl acetate was added to the sample and acidified with $0.5 \%$ trifluoroacetic acid. After vortexing and centrifugation, the organic phase was discarded and an additional ethyl acetate extraction was carried out. Finally, the peptide mixture was desalted by reverse-phase chromatography, dried, and stored at $-70^{\circ} \mathrm{C}$ until ITRAQ labeling. ITRAQ experiments were performed on 6 sets of 3 samples each. A pool of non-paired non-cancerous cervix tissue homogenates was used as a control in each set of experiments: an equal amount of total protein from lysates of 3 non-cancerous samples (non-paired controls) was pooled to generate a common reference "control sample" for CC samples comparison. The samples were dissolved in $40 \mu \mathrm{l}$ TEAB $\mathrm{pH} 8.5$ each, and the peptide was labeled using the iTRAQ reagent according to the manufacturer's instructions (Applied Biosystems) as follows: HPV16+ SCC poorly differentiated (SqPD16) reagent 114, HPV16+ SCC moderately differentiated (SqMD16) reagent 115, HPV16+ CAD moderately differentiated (AdMD16) reagent 116, HPV18+ SCC moderately differentiated (SqMD18) reagent 117, HPV31+ SCC moderately differentiated (SqMD31) reagent 118 and non-cancerous HPVnegative cervix tissue used as control reagent 121. All reactions were carried out according to the manufacturer's instructions. The peptide- 




Figure 1. Schematic view of the experimental design. Proteomics was employed for the discovery of differentially regulated proteins in cervical cancer (CC) tissues and control tissues. The clinical samples were categorized into five sub-groups: human papillomavirus-16-positive (HPV16+) squamous cell cancer (SCC) poorly differentiated (SqPD16), HPV16+ SCC moderately differentiated (SqMD16), HPV16+ cervical adenocarcinoma (CAD) moderately differentiated (AdMD16), HPV18+ SCC moderately differentiated (SqMD18), HPV31+ SCC moderately differentiated (SqMD31) and a control group. Isobaric tags for relative and absolute quantitation (ITRAQ) combined with two-dimensional liquid chromatography (2D LC$M S / M S)$, are among the most powerful methodologies in quantitative proteomics were used. Principal component analysis (PCA) was performed to obtain through Gene Set Enrichment Analysis (GSEA) the global CC proteomic profile, squamous cervical cancer proteomic profile (SCC) and cervical adenocarcinoma proteomic profile $(C A D)$.

labeled mixtures were desalted using Sep-Pak C18 Vac cartridges (Waters), pooled, and dried under vacuum. The workflow of the proteomic study is shown in Figure 1.

Peptide pre-fractionation. To increase the confidence level and coverage of the study, we performed a peptide pre-fractionation step using reverse phase (RP) chromatography before the LC-MS/MS. Peptides mixtures were subjected to RP chromatography at high $\mathrm{pH}$ on an RP-column $(4.9 \times 150 \mathrm{~mm})$ (Waters, USA) using a Binary HPLC Pump (Waters 1525) coupled to a photodiode array detector (Waters 996) set at $210 \mathrm{~nm}$. The buffer system consisted of buffers A $(50 \mathrm{mM}$ ammonium formate in water, $\mathrm{pH} 10)$ and $\mathrm{B}(50 \mathrm{mM}$ ammonium formate in $60 \%$ acetonitrile, $\mathrm{pH} 10$ ). The separation was achieved by a gradient elution as follows: 0 to $20 \mathrm{~min}, 0 \% \mathrm{~B}$; 20 to $25 \mathrm{~min}, 0$ to $5 \% \mathrm{~B} ; 25$ to $90 \mathrm{~min}, 5$ to $40 \% \mathrm{~B} ; 90$ to $105 \mathrm{~min}, 40$ to $100 \% \mathrm{~B} ; 105$ to $115 \mathrm{~min}, 100 \% \mathrm{~B} ; 115$ to $120 \mathrm{~min}, 0 \% \mathrm{~B}$ for reequilibration. The flow rate was $0.50 \mathrm{ml} / \mathrm{min}$. Thirty fractions were collected; each fraction was dried on Speed-Vac vacuum, and stored at $-80^{\circ} \mathrm{C}$ until LC-MS/MS analysis.

$L C-M S / M S$. Peptides were resuspended under initial chromatographic conditions and separated using an Agilent 1100 nano pump G2226A coupled to a hybrid triple quadrupole linear ion trap (QTRAP 3200, AB Sciex) equipped with a Nanospray II source and using data dependent acquisition (DDA). The tryptic peptides $(8 \mu \mathrm{l})$ were desalted and concentrated on a Zorbax column (Agilent 5065-
9913) before analysis on an RP column (Agilent Zorbax 300SB C18, $3.5 \mathrm{um}, 150 \times 0.075 \mathrm{~mm}$ ). Separation was done at $300 \mathrm{nl} / \mathrm{min}$ using a linear gradient. Mobile phase A was water with $0.1 \%$ formic acid (v/v). Mobile phase B was acetonitrile with $0.1 \%$ formic acid (v/v). The gradient conditions were $100 \%$ A (0 min) to $95 \%$ (10 $\mathrm{min}) ; 100 \% \mathrm{~A}(10 \mathrm{~min})$ to $75 \%$ (60 $\mathrm{min}) ; 70 \% \mathrm{~A}$ (60 $\mathrm{min})$ to $20 \%$ (70 $\mathrm{min}) ; 20 \% \mathrm{~A}(70 \mathrm{~min})$ to $20 \%(75 \mathrm{~min}) ; 20 \% \mathrm{~A}(75 \mathrm{~min})$ to $100 \%$ (76 min); and $100 \% \mathrm{~A}$ (76 min) to $100 \%$ (80 min).

Precursor ion determination was carried out using an enhanced MS scan over a mass range of $400-1,400 \mathrm{~m} / \mathrm{z}$ at 4,000 amu/s (with no trapping in Q0 and Dynamic fill time) with an ion spray voltage of 2,600 V applied to a Picotip FS360-75-15-N with ion spray gas (nitrogen). The precursor ions collided at Q2 using rolling collision energy (maximum allowed $\mathrm{CE}=80$ ). Enhanced production scans (MS/MS) were performed in a mass range of $100-1,700 \mathrm{~m} / \mathrm{z}$ at 4,000 amu/s, and collision voltages were dynamically determined. All precursor ion mass/charge ratios were confirmed with an Enhance Resolution scan.

Protein identification and quantification were carried out using MASCOT search engine (v2.2.07) against Swissport database, setting trypsin as the digestion enzyme and carbamidomethylcysteine as fixed modification. $\mathrm{N}$-terminal protein acetylation and oxidation were included as variable modifications. Proteins were identified with a $1 \%$ false discovery rate (FDR) $<1 \%$ (target-decoy). The database used for protein identification was the human reference proteome UP000005640 from UniProt repository, 
downloaded on April 30, 2016. Proteins with at least 2 razor-unique peptides identified by MS/MS were considered for quantification. These criteria resulted in 622 proteins identified in at least one experimental replicate.

Normalized spectra were extracted from each CC pool (SqMD16, SqMD16, AdM16, SqMD18, SqMD31, and control) to be analyzed, and the mass spectra were aligned by using MASCOT search engine (v2.2.07). Then the intensity mass peaks in the mass range were selected and exported in CSV file format. Protein analysis was performed for proteins with at least 2 intensity values in each analysis set. Protein abundance was normalized among conditions and the Random Forest method (miss Forest v.4;R package v2.35) was used to impute missing values (15). PCA was implemented in the protein intensity correlation matrix (Facto MineR v2.3; R package v3.5) (16) which led to protein abundance pattern for every $\mathrm{CC}$ analysis set (17). To establish whether any component could discriminate among CC analysis sets, the sample scores for each component were plotted. Once the component was found, the significant proteins that possessed discriminating capacity were identified using the squared cosine of the correlation matrix between the components and the proteins (18).

To evaluate the PCA performance on LC-MS/MS data, a t-test (significance level, 0.05) and a fold-change analysis were performed to compare protein abundance ratios among CC analysis sets. The first principal component accounts for as much of the variability in the data as possible, and similarly, each succeeding component explains as much of the remaining variability as possible (19). The first two components were considered for data classification.

SuperExactTest to clarify comprehensive relationships among CC analysis sets. The SuperExactTest (SET) was implemented to visualize comprehensive relationships among CC analysis sets. SET provides the theoretical framework to compute the statistical distributions of multi-set intersections based upon combinatorial theory and a procedure to accurately calculate the exact probabilities of multi-set intersections (20).

Gene set enrichment analysis to elucidate pathways in CC. The mean fold change data of the two experimental replicates were used to produce a preordered ranked gene list data set, then tested for enrichment by Gene set enrichment analysis (GSEA v. 2.0, Broad Institute, Cambridge, MA, USA) (21). Gene sets were generated and modified with biochemical pathway data from the Kyoto Encyclopedia of Genes and Genomes (KEGG; www.genome.jp/kegg). A number of gene sets were differentially enriched $(p<0.1$ and FDR $<0.25)$ in each cancer tissue compared to control.

Immunohistochemical (IHC) analysis. A representative section was taken from tumor specimens and placed in a 100\% formaldehyde solution. The fixed tissue was dehydrated with graded alcohols and embedded in paraffin wax. CC specimen sections $(6-\mu \mathrm{m}$ thick) were cut and mounted on Super frost plus slides (VWR; Thermo Fisher Scientific). The sections were then deparaffinized with xylene and washed in $100 \%$ alcohol. The slides were incubated at room temperature (RT) in $3 \%(\mathrm{v} / \mathrm{v}) \mathrm{H}_{2} \mathrm{O}_{2}$ in methanol for 30 min to block endogenous peroxidase activity. The slides were then rehydrated through graded alcohols, washed in PBS, pH 7.5 and stained using a Ventana Medical Systems kit (Roche Tissue Diagnostics, Oro Valley, AZ, USA) according to the manufacturer's guidelines from the antibody incubation step.

The antibodies used were: anti-RAB14 1:200 (ab28639; Abcam, Cambridge, UK), anti-RCN3 1:200 (NBP2-13213; Novus Biologicals,
Centennial, CO, USA), and Anti-p16 (725-4713; CINtec ${ }^{\circledR}$ Histology, Roche Diagnostics, Rotkreuz, Switzerland), which was used as a positive control for CC tissues. Staining was assessed in the tumor area using the plug-in IHC profiler from ImageJ.

Plasmid and lentivirus production. Gene expression of RAB14 and RCN3 was carried out using plasmid expression vectors. Viral particles containing the RAB14 sequence gene were produced by a cotransfection using the plasmids psPax2 (12260; Addgene), pMD2G (Addgene no. 12259), pL-SIN-EF1a-EGFP (21320; Addgene), and RAB14 WT (plasmid \#61493; gift by Dr. Curt Civin, Addgene). Viral particle production was performed in HEK $293 \mathrm{~T}$ cell line by using lipofectamine 3000 (L30000015; Invitrogen). According to the product instructions, viral particles produced in cultured cells were harvested at $48 \mathrm{~h}$ post-transfection and cleared by a low-affinity protein filter $(0.45$ $\mu \mathrm{m}$ pore size) and frozen at $-70^{\circ} \mathrm{C}$ until further use. PCDNA 3.1 red fluorescent protein (RFP) (13032; Addgene) RCN3 was generated using shrimp alkaline phosphatase (ALP) (783901000UN; Thermo Fisher) to avoid plasmid recirculation, followed by T4 DNA ligase cloning (EL0011; Invitrogen). pCDNA3.1RFP-RCN3 plasmid was transfected into $E$. coli $\mathrm{DH} 5 \alpha$ and selected by carbenicillin resistance, grown in Luria-Bertani (LB) broth media and verified by detection of RCN3 by PCR. pCDNA 3.1 plasmid purification was performed using the Genomic DNA Purification Kit (K0512; Thermo Fisher) and the purified PCDNA3.1 RFP-RCN3 was stored at $-70^{\circ} \mathrm{C}$ until use in transfection.

Cell transfection. HeLa cells were grown until reaching $80 \%$ cell confluence using RPMI 1640 5\% fetal bovine serum. Transfection with the plasmids mentioned above was performed using lipofectamine 3000 (L30000015; Invitrogen) in p60 cell culture plates. In addition, cells were transfected with pCDNA empty vector (Mock), as control. After $48 \mathrm{~h}$ post-infection/transfection, cells were harvested and washed in PBS pH 7.5, counted and inoculated in immunodeficient mice.

Tumor xenograft mouse model. In this study, 4-6 old week old nude female athymic BALB/c nu/nu mice were used. The Bioethics Committees of UNAM and INCan approved the protocol used for animal handling in this study. To develop tumor xenografts in mice, $2 \times 10^{6} \mathrm{HeLa}$ cells transfected with RAB14 or RCN3 and injected subcutaneously in one flank of nude mice. The signs of tumor formation were observed daily and measured every week in triplicate. Control animals were injected with wild-type HeLa cells in serum-free cell culture media. Tumor volume was measured using the Attia-Weiss formula: $\mathrm{a} \times \mathrm{b} 2 \times 0.4$, where $\mathrm{a}=$ largest diameter and $\mathrm{b}=$ smallest diameter of tumor. After 8 weeks, mice were sacrificed, and the subcutaneous tumors were removed, photographed, fixed in $4 \%$ formaldehyde and embedded in paraffin. A representative section was taken from tumors induced by RAB14 or RCN3 HeLa transfected cells to measure the level of protein expression using wild-type HeLa cells tumors as a control.

\section{Results}

Patients and histopathological diagnosis. To perform quantitative proteomics, the histopathological diagnosis of each sample was performed by microscopic examination of a 5- $\mu \mathrm{m}$ thick section of each research tissue sample. The eighteen samples were classified into 6 groups (SqPD16, 
Table I. Statistically significant protein changes were classified in upregulated, downregulated or non-differentially expressed proteins in CC, SCC and CAD analysis pools.

\begin{tabular}{lrcr}
\hline Protein expression & \multicolumn{3}{c}{ Cancer type } \\
\hline & CC & SCC & CAD \\
\hline Up-regulated & 40 & 60 & 41 \\
Non-differentially expressed & 571 & 552 & 565 \\
Down-regulated & 11 & 10 & 16 \\
\hline
\end{tabular}

CC: Cervical cancer; SCC: squamous cervical cancer; CAD: cervical adenocarcinoma.

SqMD16, AdMD16, SqMD18, SqMD31 and control), each of which consisted of 3 samples, as described in Materials and Methods.

Proteomics. Each group consisted of 3 individual samples, and all 18 samples were analyzed. A total of 622 proteins identified and quantified in both replicates (Supplemental Table I) were processed by PCA, a statistical method designed to alleviate the degree of complexity in highdimensional data but allowing the retention of trends and patterns (19), which is done by transforming the data into fewer dimensions that act as feature summaries.

According to PCA results, the component scores of spectra were plotted for Dimension 2 (Dim2; Y-axis) and Dimension 1 (Dim1; X-axis). In PCA, the projections indicated the separation of the control group (non-cancerous, HPV-negative cervical tissue) from the other groups (HPV+, cervical cancer tissue). SqMD16 and SqPD16 tended to be close and SqMD31 and SdMD18 suggested certain tumor proteins in common. In addition, the highest correlation among all $\mathrm{CC}$ analyzed groups was observed between SqMD16 and SqPD16 samples, suggesting HPV16 contribution was similar in moderately differentiated SCC samples and SCC poorly differentiated. Finally, we discovered a pronounced difference between SCC (SqPD16, SqMD16, SqMD31 and SqMD18) and CAD proteomic profile, which highlights the differences at the proteome level between SCC and CAD (Figure 2). The proteins obtained from the PCA analysis were also classified according to gene ontology (GO)-biological process (BP) classification. The BP analysis showed that $25 \%$ of the proteins identified and quantified belong to the exocytosis pathway (regulated exocytosis and exocytosis). Protein binding was the most predominant category for proteins in the molecular function classification, followed by structural molecule activity. For cell component classification proteins identified in $\mathrm{CC}$, more than a half of the classified proteins were related to vesicle and extracellular space components (Figure 3). Next, PCA was used to estimate the similarity between them. Statically significant proteins were retrieved

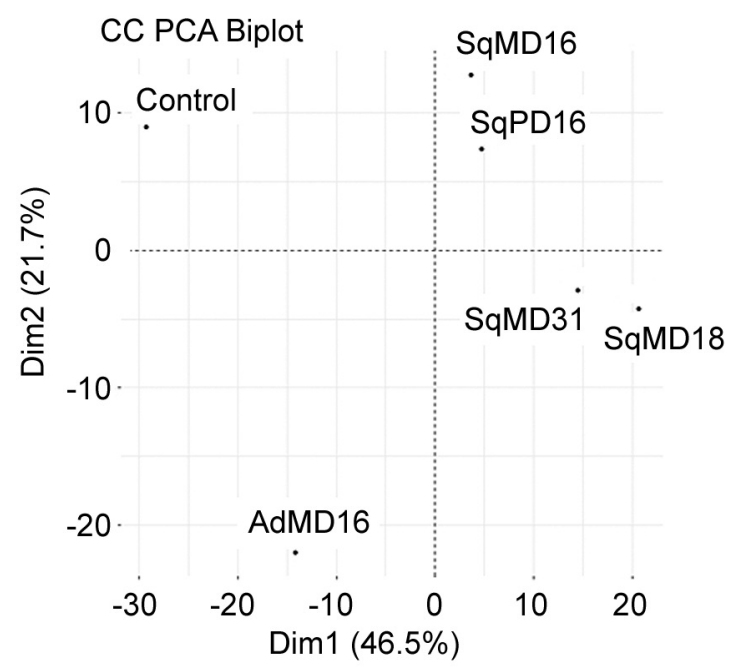

Figure 2. The biplot gives an indication about clustering and trends present in the protein profiles. Scores of similar cervical cancer (CC) pools will tend to form clusters whereas dissimilar samples will be located at greater mutual distances. The results demonstrate that SCC protein profiles constitute a cluster; SqMD31 and SqMD18 are closer relatives than SqMD16 and SqPD16 although they both belong to SCC profile. AdMD16 is located at a larger distance from the rest of CC groups. Control is located near 10 over the dimension 2 (Dim2) axis, far from the CC groups.

over (1.9) or below (-1.9) fold-change compared to control. Also SET was completed to visualize up-regulated and downregulated proteins in CC multi-set intersections. Results are shown in Figure 4 and Table I. CAD showed a more specific proteomic pattern compared to SCC and CC. Out of 622 proteins, 597 were included in GSEA, considering only those collapsed in the analysis software data set.

GSEA to elucidate pathways in CC. The fold-change data, obtained from 2 experimental replicates were used to formulate a gene list data set, further tested by GSEA (GSEA v. 2.0, Broad Institute, Cambridge, MA, USA) (19). Gene sets were generated and modified using biochemical pathway data from the Kyoto Encyclopedia of Genes and Genomes (KEGG; www.genome.jp/kegg). Several sets of genes were differentially enriched $(p<0.1$ and FDR $<0.25)$ in each CC tissue compared to the control. The results obtained from GSEA provided 39 sets of genes ( $p$-value $\leq 0.1$ or FDR $\leq 0.25$ ) (Supplemental Table II and Supplemental Figure 1), of which 21 gene sets $(p$-value $\leq 0.1$ and $F D R \leq 0.25)$ were chosen according to the GSEA parameters and criteria. These gene sets are statistically enriched in at least one $\mathrm{CC}$ cancer group. Next, the down-regulated and up-regulated pathways from GSEA were classified (Table II) including main proteins for each set. Focal adhesion, protein digestion and absorption, papillomavirus, and extracellular matrix receptor (ECM) 


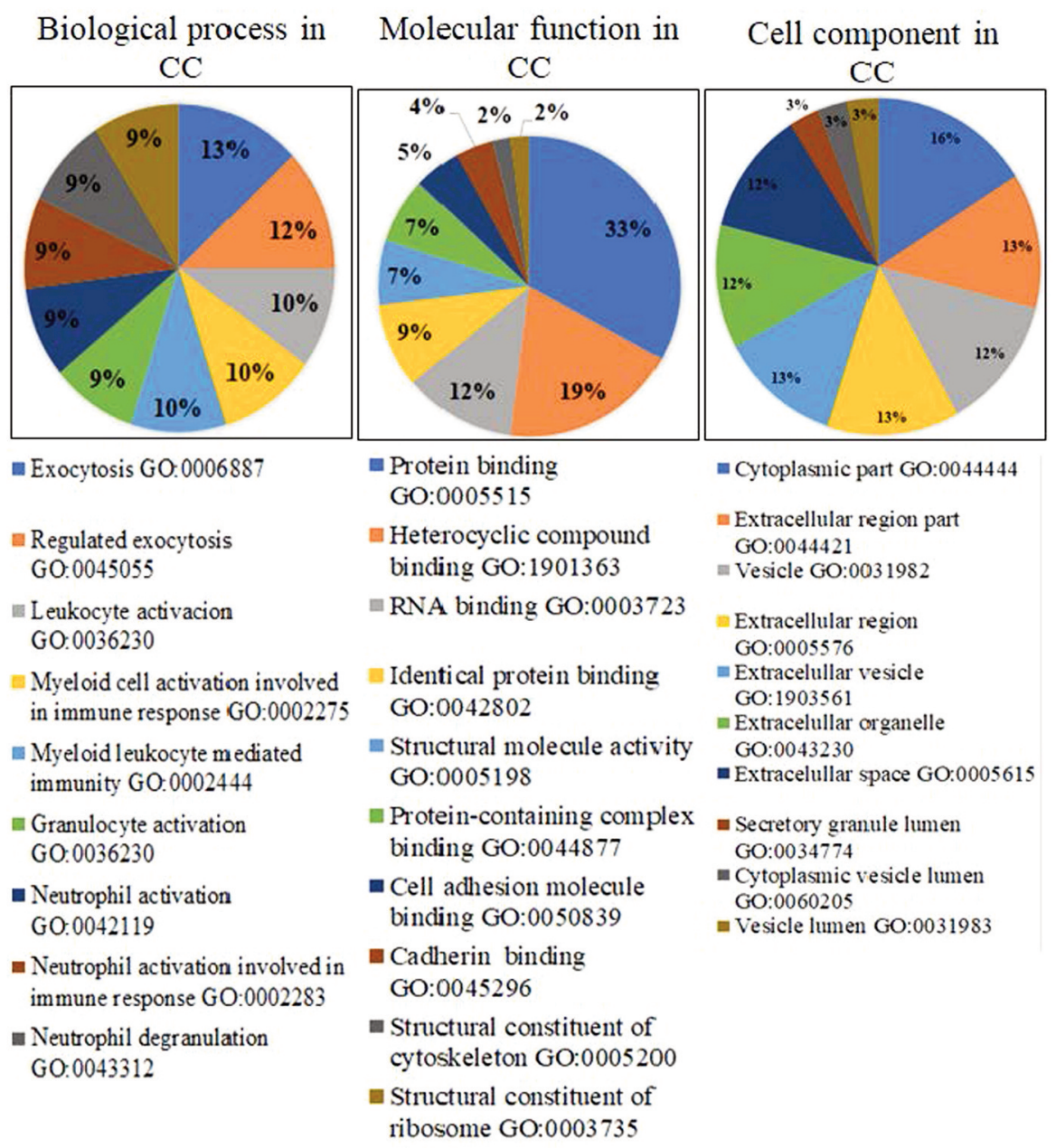

Figure 3. A total of 622 proteins identified and quantified by isobaric tags for relative and absolute quantitation (ITRAQ) were grouped according to gene ontology classification by biological process. Regulated exocytosis and exocytosis together accounted for 25\% of total classification. CC, Cervical cancer.

interaction were the most the overrepresented pathways in GSEA. Compared to the control, one of the most up-regulated pathways in $\mathrm{CC}$ was calcium signaling; where voltage dependent anion channel 1 (VDAC-1) was identified as a critical interactor (Supplemental Table III). On the other hand, the ECM-receptor interaction was one of the most downregulated pathways found in $\mathrm{CC}$ compared to control. This result is supported by the downregulation of collagens (COL6A3, COL6A1, COL14A1, and COL6A2) that we experimentally discovered in our study. Statistically significant proteins obtained by PCA and a fold-change analysis were classified into 3 groups: i) proteins differentially expressed in SCC compared to control (Table III), ii) proteins differentially expressed in CAD compared to control (Table IV), and iii) common proteins between SCC and $\mathrm{CAD}$ compared to control (Table V). The information included in the tables was obtained from scientific reports that considered protein participation in the hallmarks of cancer, and BP was annotated to the proteins that no reports of participation in cancer were found. SCC_CRTL (Table III) showed that almost $50 \%$ of the proteins included are related to activating invasion and metastasis. The comparison of SCC with control showed that 22 proteins were overexpressed: activating invasion and metastasis was the leading category with 9 proteins (CALL5, ZN185, GT251, S10AE, K1C15, FLNB, K2C6C, NEBU, YBOX3).

Compared to the control (Table IV), the classification of CAD proteins showed resisting cell death as the main category of proteins obtained. Protein S100-A9 (S10A9), ribosomebinding protein 1 (RRBP1), protein S100-A13 (S10AD), histone $\mathrm{H} 2 \mathrm{AX}(\mathrm{H} 2 \mathrm{AX})$ and protein S100-A12 (S10AC) were classified in the main category. Endoplasmic reticulum 


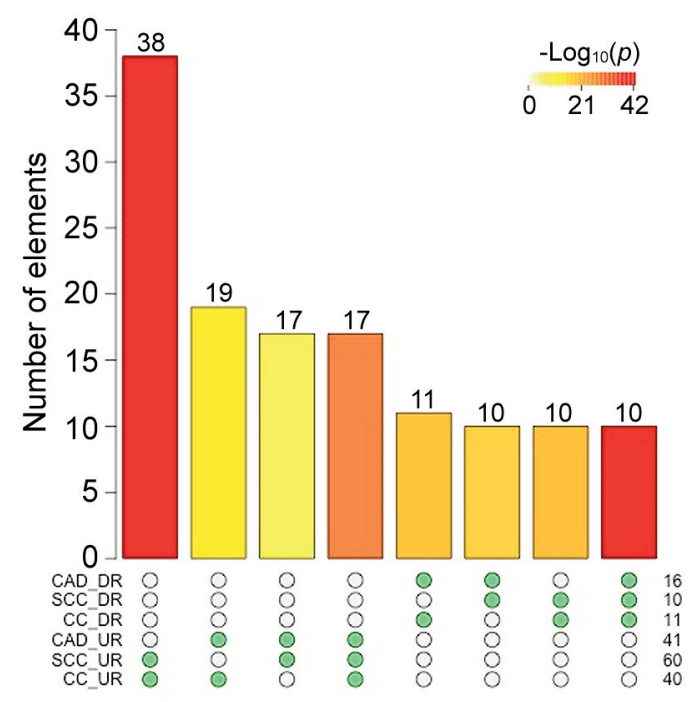

Figure 4. SuperExactTest (SET) was used to establish multi-set intersections among CC analysis sets, for up-regulated (UR) and downregulated (DR) proteins. A total of $17 \mathrm{UR}$ and $10 \mathrm{DR}$ proteins were common in all the three analysis sets (CC, SCC and CAD). The color intensity of the bars represents the p-value significance of the intersections. CC, Cervical cancer; SCC, squamous cell cancer; CAD, cervical adenocarcinoma.

ribosomal binding protein 1 (RRBP1) is a transporter located in the rough endoplasmic reticulum (ER). Twenty-seven proteins were shared between SCC and CAD compared to control. Resisting cell death and activating invasion and metastasis were the main common cell function categories found in SCC and CAD. The down-regulated proteins in SCC and CAD compared to control were related to cell adhesion. Furthermore, the $10 \mathrm{kDa}$ heat shock protein $(\mathrm{CH} 10)$ was upregulated in SCC and CAD compared to control.

In this study, prosaposin (SAP) was overexpressed in general terms in CC samples compared to control. However, we emphasize the greater overexpression of SAP at the proteomic level in CAD compared to control. Considering this difference, we hypothesized that SAP might be related to promoting the survival of tumor $\mathrm{CC}$ cells under stress conditions, contributing to the worse clinical outcome in CAD compared to SCC.

Reticulocalbin 3 (RCN3) was overexpressed in both CAD and SCC, compared to control tissue. For this reason, we decided to perform further in vivo analysis to investigate the role in $\mathrm{CC}$ development since the evidence associated with this protein in $\mathrm{CC}$ it is still scarce.

IHC analysis. IHC analysis was performed to verify protein expression in $9 \mathrm{CC}$ tumor samples. These samples were cut and stained with hematoxylin and eosin, p16, RAB14, and RCN3 antibodies. IHC slides were evaluated using IHC profiler plug-in, and the result was positive for 6/9 samples analyzed for p16 IHC (considered as a positive control for CC), 6/9 positive for RAB 14 protein, and 5/9 positive tissue samples for RCN3 protein. Three different samples are shown in Figure 5.

RAB14 and RCN3, two ER proteins up-regulated in CC, were selected to further study their role in tumor biology. RAB14 was overexpressed in SqPD16 in 2 replicates, and RCN3 was overexpressed in CC analysis groups compared to control tissue by PCA data. Evidence provided at the proteomics level led us to perform in vivo studies considering RCN3 was overexpressed (1.94-fold-change) in CC compared to the control (Table V), and RAB14 was overexpressed (3.12fold-change) in SqPD16 compared to the control (Supplemental Table I).

Tumor xenograft model. RAB14 and RCN3 HeLa transfected cells were separately inoculated subcutaneously into female $\mathrm{nu} / \mathrm{nu}$ mice. Tumor formation was visible on day 16 ; HeLa RCN3 tumors showed a moderate effect on tumor growth development until day 47. In contrast, HeLa RAB14expressing cells showed effects on tumor size from the beginning to the end of the tumor formation experiment (Figure 6A and B). The expression of RCN3 and RAB14 proteins in the xenograft tumors was evaluated by Western blot by selecting the smallest tumor and the largest tumor of each (Figure 6D). For RAB14 protein, Western blot analysis showed that tumor volume was positively correlated with RAB14 protein expression (Figure 6E). RCN3 tumors showed higher RCN3 protein expression over vector and WT HeLa control cells; however, a moderate relation was found between RCN3 protein expression and tumor size increment was visible until day 47 . RAB14-inoculated mice developed larger tumors than those with control cells. The increase in tumor size in RAB14 was most pronounced around day 35 and was maintained until day 47, showing and confirming the role of RAB14 in tumorigenesis, as shown in Figure 6.

\section{Discussion}

CC remains one of the most common types of cancer in women worldwide. Although CC early detection and public health programs have decreased the number of cases and mortality rates, the response to treatment in $\mathrm{CC}$ variants remains poor. Detection systems such as the Pap and HPV DNA test have reduced the incidence and mortality of CC. However, CAD has shown a poor prognosis for patients and a greater probability of distant recurrence than SCC (76). In this study, global CC, SCC, and CAD proteomics profiles were obtained by comparing $\mathrm{CC}$ tissues with control tissue. Six hundred twenty-two proteins identified and quantified by LC/MS were processed by PCA, which allowed us to group and obtain global proteomic patterns that we classified as $\mathrm{CC}$, 
Table II. Statistically significant enrichment pathways in cervical cancer according to gene set enrichment analysis (GSEA).

\begin{tabular}{|c|c|c|c|}
\hline Cervical cancer tissue type & Pathway & $p$-Value & Involved proteins \\
\hline \multirow[t]{14}{*}{ CC (SCC \& CAD) } & Cell cycle & $<0.0001$ & ARHGDIB CALML3 \\
\hline & Neurotrophin signaling pathway & 0.0011 & CAMP SFN LYZ \\
\hline & Oocyte meiosis & 0.0012 & VDAC1 VDAC3 YWHAB \\
\hline & Salivary secretion & 0.0305 & YWHAE YWHAH \\
\hline & Calcium signaling pathway & 0.0277 & $\begin{array}{c}\text { YWHAZ YWHAQ } \\
\text { CALML5 }\end{array}$ \\
\hline & Protein digestion and absorption & $<0.0001$ & COL1A1 COL1A2 \\
\hline & ECM-receptor interaction & $<0.0001$ & COL2A1 COL6A1 \\
\hline & Papillomavirus & $<0.0001$ & COL6A2 COL6A3 \\
\hline & Gap junction & $<0.0001$ & PPP1CC TUBB6 \\
\hline & Focal adhesion & $<0.0001$ & TUBA4A COL14A1 \\
\hline & & & VCL FLNA TUBB \\
\hline & & & TUBA1A TUBB2B \\
\hline & & & TUBA1B TUBB4B \\
\hline & & & TUBA1C \\
\hline \multirow[t]{16}{*}{$\mathrm{SCC}$} & Cell cycle & $<0.0001$ & ARHGDIB CALML3 \\
\hline & Oocyte meiosis & $<0.0001$ & CAMP CTSD SFN \\
\hline & Neurotrophin signaling pathway & $<0.0001$ & HSP90AA1 HSP90AB1 \\
\hline & Tuberculosis & 0.0160 & HSPD1 LSP1 STAT1 \\
\hline & Plant-pathogen interaction & 0.0224 & HSP90B1 YWHAB \\
\hline & & & YWHAE YWHAH \\
\hline & & & YWHAZ YWHAQ \\
\hline & & & CALML5 CYCS \\
\hline & Protein digestion and absorption & $<0.0001$ & COL1A1 COL1A2 \\
\hline & Papillomavirus & $<0.0001$ & COL2A1 COL6A1 \\
\hline & ECM-receptor interaction & $<0.0001$ & COL6A2 COL6A3 \\
\hline & Gap junction & $<0.0001$ & TUBA4A COL14A1 \\
\hline & Focal adhesion & $<0.0001$ & TUBA1A TUBA1B \\
\hline & & & TUBB4B TUBB6 \\
\hline & & & TUBA1C TUBB \\
\hline & & & TUBB2B \\
\hline \multirow[t]{13}{*}{ SCC compared to CAD } & Oocyte meiosis & $<0.0001$ & ALDOA ARHGDIB SFN \\
\hline & Cell cycle & 0.002 & GPI PFKL PFKP PGM1 \\
\hline & Pentose phosphate pathway & 0.002 & TUBA4A YWHAB \\
\hline & Glycolysis/gluconeogenesis & 0.003 & YWHAE YWHAH \\
\hline & Gap junction & 0.008 & YWHAZ TUBA1A \\
\hline & & & TUBA1B TUBB4B \\
\hline & & & YWHAQ CALML5 TUBB6 \\
\hline & & & TUBA1C TUBB TUBB2B \\
\hline & Systemic lupus erythematosus & 0.013 & APOA1 COL1A1 COL1A2 \\
\hline & Protein digestion and absorption & 0.012 & COL2A1 ELANE H2AFX \\
\hline & African trypanosomiasis & 0.046 & HBA2 HBB COL14A1 \\
\hline & & & HIST1H3F HIST1H2AG \\
\hline & & & H2AFY H2AFV \\
\hline \multirow[t]{18}{*}{ CAD } & Systemic lupus erythematosus & 0.001 & ATP5B ATP5D \\
\hline & Cardiac muscle contraction & 0.004 & ATP6V1E1 ATP5O \\
\hline & Oxidative phosphorylation & 0.049 & CALML3 CAMP \\
\hline & Tuberculosis & 0.076 & ELANE H2AFX \\
\hline & Peroxisome & 0.084 & HSPD1 LSP1 NDUFS4 \\
\hline & & & SCP2 SOD1 TPM1 \\
\hline & & & ТРМ2 ТРМ3 ТРМ4 \\
\hline & & & HIST1H3F HIST1H2AG \\
\hline & & & H2AFY NDUFA13 \\
\hline & & & CYCS H2AFV \\
\hline & Protein digestion and absorption & $<0.0001$ & A2M SERPINC1 CPAMD1 \\
\hline & Papillomavirus & $<0.0001$ & COL2A1 COL6A1 \\
\hline & Gap junction & $<0.0001$ & COL6A2 COL6A3 \\
\hline & ECM-receptor interaction & 0.003 & KNG1 PKM PLG \\
\hline & Complement and coagulation cascades & 0.011 & TUBA4A COL14A1 \\
\hline & & & TUBA1A TUBA1B \\
\hline & & & TUBB4B TUBB6 TUBA1C \\
\hline & & & TUBB TUBB2B \\
\hline
\end{tabular}

CC: Cervical cancer; SCC: squamous cervical cancer; CAD: cervical adenocarcinoma. 
Table III. Differentially expressed proteins in SCC.

\begin{tabular}{|c|c|c|c|c|c|c|c|c|c|c|}
\hline Number & Name & CC_CTRL $^{1}$ & $p$-Value ${ }^{2}$ & SCC_CTRL ${ }^{1}$ & $p$-Value ${ }^{2}$ & CAD_CTRL ${ }^{1}$ & $p$-Value ${ }^{2}$ & $\mathrm{SCC}_{-} \mathrm{CAD}^{1}$ & $p$-Value ${ }^{2}$ & Cell function \\
\hline 1 & CALL5 & 1.829 & 0.067 & 2.073 & 0.041 & 0.431 & 0.747 & 1.642 & 0.049 & $\begin{array}{l}\text { Activating invasion and } \\
\text { metastasis }(21-23)\end{array}$ \\
\hline 2 & OSTF1 & 1.888 & 0.001 & 2.062 & 0.000 & 1.385 & 0.046 & 0.677 & 0.025 & Ossification \\
\hline 3 & COTL1 & 1.801 & 0.049 & 1.992 & 0.039 & 0.874 & 0.504 & 1.118 & 0.191 & $\begin{array}{l}\text { Sustaining proliferative } \\
\text { signaling }(22-24)\end{array}$ \\
\hline 4 & ZN207 & 1.895 & 0.000 & 1.991 & 0.000 & 1.758 & 0.026 & 0.233 & 0.288 & Cell division \\
\hline 5 & 1433B & 1.794 & 0.000 & 1.988 & 0.000 & 0.716 & 0.387 & 1.273 & 0.041 & Resisting cell death (23-25) \\
\hline 6 & ZN185 & 1.678 & 0.082 & 1.981 & 0.072 & 1.212 & 0.293 & 0.769 & 0.357 & $\begin{array}{l}\text { Activating invasion and } \\
\text { metastasis }(24-26)\end{array}$ \\
\hline 7 & $1433 \mathrm{G}$ & 1.750 & 0.000 & 1.936 & 0.000 & 0.684 & 0.415 & 1.252 & 0.056 & Resisting cell death (23-25) \\
\hline 8 & PERE & 1.602 & 0.048 & 1.933 & 0.037 & 0.837 & 0.593 & 1.097 & 0.342 & $\begin{array}{l}\text { Tumor promoting } \\
\text { inflammation }(25-27)\end{array}$ \\
\hline 9 & GT251 & 1.837 & 0.118 & 2.063 & 0.119 & 0.673 & 0.660 & 1.390 & 0.191 & $\begin{array}{l}\text { Activating invasion and } \\
\text { metastasis }(26-28)\end{array}$ \\
\hline 10 & S10AE & 1.898 & 0.003 & 2.040 & 0.003 & 1.571 & 0.057 & 0.469 & 0.162 & $\begin{array}{l}\text { Activating invasion and } \\
\text { metastasis }(27-29)\end{array}$ \\
\hline 11 & $\mathrm{~K} 1 \mathrm{C} 15$ & 1.708 & 0.010 & 1.997 & 0.006 & 0.630 & 0.637 & 1.367 & 0.165 & $\begin{array}{l}\text { Activating invasion and } \\
\text { metastasis }(28-30)\end{array}$ \\
\hline 12 & FLNB & 1.737 & 0.000 & 1.960 & 0.000 & 1.032 & 0.308 & 0.929 & 0.158 & $\begin{array}{l}\text { Activating invasion and } \\
\text { metastasis }(29-31)\end{array}$ \\
\hline 13 & GLU2B & 1.807 & 0.000 & 1.921 & 0.000 & 1.663 & 0.024 & 0.258 & 0.306 & $\begin{array}{l}\text { Cellular protein } \\
\text { metabolic process }\end{array}$ \\
\hline 14 & $1433 \mathrm{~F}$ & 1.738 & 0.000 & 1.921 & 0.000 & 0.711 & 0.404 & 1.210 & 0.063 & Resisting cell death (23-25) \\
\hline 15 & PLIN3 & 1.767 & 0.000 & 1.970 & 0.001 & 1.228 & 0.032 & 0.742 & 0.021 & Resisting cell death (30-32) \\
\hline 16 & $\mathrm{~K} 2 \mathrm{C} 6 \mathrm{C}$ & 1.654 & 0.001 & 1.935 & 0.001 & 0.683 & 0.544 & 1.253 & 0.143 & $\begin{array}{l}\text { Activating invasion and } \\
\text { metastasis }(28-30)\end{array}$ \\
\hline 17 & NONO & 1.896 & 0.001 & 1.932 & 0.003 & 1.585 & 0.066 & 0.347 & 0.236 & $\begin{array}{l}\text { Sustaining proliferative } \\
\text { signaling }(31-34)\end{array}$ \\
\hline 18 & PSA2 & 1.673 & 0.055 & 1.904 & 0.051 & 0.776 & 0.546 & 1.128 & 0.230 & Resisting cell death (33-35) \\
\hline 19 & NEBU & 1.824 & 0.008 & 2.065 & 0.006 & 1.303 & 0.310 & 0.762 & 0.323 & $\begin{array}{l}\text { Activating invasion and } \\
\text { metastasis }(34-36)\end{array}$ \\
\hline 20 & TBCA & 1.808 & 0.000 & 1.951 & 0.000 & 1.456 & 0.023 & 0.495 & 0.022 & Resisting cell death (35-37) \\
\hline 21 & YBOX3 & 1.756 & 0.000 & 1.948 & 0.000 & 1.136 & 0.083 & 0.811 & 0.020 & $\begin{array}{l}\text { Activating invasion and } \\
\text { metastasis }(36-38)\end{array}$ \\
\hline 22 & $1433 \mathrm{~T}$ & 1.741 & 0.000 & 1.930 & 0.000 & 0.672 & 0.394 & 1.258 & 0.039 & Resisting cell death (23-25) \\
\hline
\end{tabular}

${ }^{1}$ Protein expression fold-change; ${ }^{2} p$-Value according to Gene Set Enrichment Analysis. CC: Cervical cancer; SCC: squamous cervical cancer; CAD: cervical adenocarcinoma; CTRL: control.

SCC, and CAD. This analysis aimed at finding common protein patterns in $\mathrm{CC}$ and specific ones in SCC and CAD. BP analysis classified $25 \%$ of proteins as proteins related to exocytosis and $24 \%$ as components of extracellular vesicle and organelle components. The experimental data that we obtained emphasizes the importance of endo/exocytosis proteins in CC. Recent evidence has suggested that altered protein trafficking routes/networks are preferentially involved in acquiring pro-metastatic traits (77). Endosomal recycling has been reported to play a central role in integrating circuits linked to metastasis and resistance to cell death, the two most overrepresented protein categories in CC found in our study. In particular, the family of Ras-related proteins is involved in acquiring metastatic traits and resistance to apoptosis mediated by endosomal recycling (78).
From the set of 622 proteins identified and quantified in this study (Supplemental Table I), 597 were subjected to GSEA, and were classified according to experimental evidence reported in the bibliography. Differentially expressed SCC proteins showed activating invasion and metastasis as the primary cell function in SCC (Table III), resisting cell death for CAD differentially expressed proteins (Table IV), and resisting cell death and activating invasion and metastasis as the two common cell function categories in SCC and CAD compared to control (Table V).

RRPB1 has been shown to be overexpressed in lymph node metastasis in CC patient samples (39) (Table IV). In addition, RRPB1 is involved in endoplasmic reticulum stress (ERS) release in lung cancer, as a response to increasing tumor cell proliferation functions like protein synthesis, 
Table IV. Differentially expressed proteins in CAD.

\begin{tabular}{|c|c|c|c|c|c|c|c|c|c|c|}
\hline Number & Name & CC_CTRL $^{1}$ & $p$-Value ${ }^{2}$ & SCC_CTRL $^{1}$ & $p$-Value ${ }^{2}$ & CAD_CTRL ${ }^{1}$ & $p$-Value ${ }^{2}$ & SCC_CAD $^{1}$ & $p$-Value ${ }^{2}$ & Cell function \\
\hline 1 & S10A9 & 1.726 & 0.001 & 1.546 & 0.001 & 2.441 & 0.163 & -0.895 & 0.243 & Resisting cell death (37-39) \\
\hline 2 & RRBP1 & 1.597 & 0.018 & 1.558 & 0.039 & 2.040 & 0.206 & -0.483 & 0.444 & Resisting cell death (38-41) \\
\hline 3 & S10AD & 1.575 & 0.054 & 1.578 & 0.089 & 2.153 & 0.035 & -0.575 & 0.040 & Resisting cell death (40-42) \\
\hline 4 & $\mathrm{H} 2 \mathrm{AX}$ & 1.489 & 0.046 & 1.397 & 0.092 & 2.149 & 0.065 & -0.752 & 0.000 & Resisting cell death (41-44) \\
\hline 5 & CEAM5 & 1.650 & 0.060 & 1.338 & 0.147 & 2.600 & 0.313 & -1.262 & 0.410 & $\begin{array}{l}\text { Activating invasion } \\
\text { and metastasis }(43-45)\end{array}$ \\
\hline 6 & GPVI & 1.807 & 0.014 & 1.732 & 0.032 & 2.322 & 0.287 & -0.589 & 0.520 & $\begin{array}{l}\text { Activating invasion and } \\
\text { metastasis }(44-47)\end{array}$ \\
\hline 7 & S10A6 & 1.470 & 0.000 & 1.327 & 0.001 & 2.026 & 0.205 & -0.700 & 0.358 & $\begin{array}{l}\text { Activating invasion } \\
\text { and metastasis }(46-48)\end{array}$ \\
\hline 8 & ELNE & 1.853 & 0.001 & 1.870 & 0.001 & 2.125 & 0.196 & -0.255 & 0.558 & $\begin{array}{l}\text { Tumor promoting } \\
\text { inflammation }(47-50)\end{array}$ \\
\hline 9 & CEAM8 & 1.310 & 0.141 & 1.085 & 0.246 & 2.014 & 0.304 & -0.929 & 0.451 & $\begin{array}{l}\text { Tumor promoting } \\
\text { inflammation (49-51) }\end{array}$ \\
\hline 10 & S10AC & 1.107 & 0.091 & 0.927 & 0.211 & 1.936 & 0.324 & -1.009 & 0.415 & $\begin{array}{l}\text { Resisting cell } \\
\text { death }(40-42)\end{array}$ \\
\hline 11 & $\mathrm{CYC}$ & 1.610 & 0.007 & 1.577 & 0.011 & 1.928 & 0.096 & -0.351 & 0.337 & $\begin{array}{c}\text { Deregulating cellular } \\
\text { energetics }(45-47),(50-52)\end{array}$ \\
\hline 12 & $\mathrm{~K} 2 \mathrm{C} 8$ & 1.410 & 0.023 & 1.507 & 0.075 & 1.910 & 0.021 & -0.403 & 0.066 & $\begin{array}{l}\text { Activating invasion } \\
\text { and metastasis (51-53) }\end{array}$ \\
\hline 13 & CAMP & 1.693 & 0.052 & 1.606 & 0.096 & 2.339 & 0.161 & -0.732 & 0.308 & $\begin{array}{l}\text { Tumor promoting } \\
\text { inflammation (52-55) }\end{array}$ \\
\hline 14 & CYTA & 1.569 & 0.004 & 1.346 & 0.026 & 2.336 & 0.120 & -0.990 & 0.198 & $\begin{array}{l}\text { Evading growth } \\
\text { suppressors (54-56) }\end{array}$ \\
\hline
\end{tabular}

${ }^{1}$ Protein expression fold-change; ${ }^{2} p$-Value according to Gene Set Enrichment Analysis. CC: Cervical cancer; SCC: squamous cervical cancer; CAD: cervical adenocarcinoma; CTRL: control.

folding, and secretion. This was shown by the expression of the ectopic protein RRPB1 in non-small cell lung cancer cell lines when ERS was induced using tunicamycin (40). Furthermore, it has been reported that RRBP1 is highly expressed in prostate cancer and correlates with poor prognosis, and thus has been suggested as a potential biomarker in PCa (79) and ovarian cancer (80). Patients with higher expression of RRBP1 have been reported to have worse overall survival; hence RRBP1 has also been suggested as a target for epithelial ovarian cancer treatment (80).

$\mathrm{RCN} 3$ is a $\mathrm{Ca}^{2+}$ binding protein in the secretory pathway and is located in the ER (81). To date, the evidence of RCN3 in relation to cancer development is insufficient compared to reticulocalbin 1 (RCN1). RCN1 is a member of the $\mathrm{Ca}^{2+}$ binding protein family expressed in the highly metastatic prostate cancer cell line PC-3 (82). RCN1 mRNA expression increased in the highly invasive breast cancer cell line MDAMB-435, compared to poorly invasive MCF-7 (83). Furthermore, RCN1 has been suggested as a potential biomarker for renal cell carcinoma when discovered by proteomic approach and validated by IHC in 21 of 24 renal cell cancer paired tissue samples (84). In prostate cancer, RCN1 expression arose in bone marrow endothelial cells (BMECs), increased in the presence of tumor necrosis factor $\alpha$ (TNF- $\alpha)$, a pro-inflammatory cytokine often expressed in prostate cancer patients with very advanced metastasis (85). RCN2 is another member of the reticulocalbin family which, when detected overexpressed in hepatocellular cell cancer (HCC), has been involved in cell proliferation and tumor growth, presumably by regulating epidermal growth factor receptor (EGFR) activation and the extracellular signal-regulated kinase (ERK) pathway (86). RCN1 and RCN2, in contrast with RCN3, have been extensively studied. This notion guided us to explore the role of RCN3 in oncogenesis, especially in CC.

In the present study, we found that the expression of the $\mathrm{RCN} 3$ protein was upregulated in all $\mathrm{CC}$ analysis sets when compared to the control (Table V). IHC analysis showed positive expression of RCN3 in 5/9 samples. Moreover, RCN3overexpressing HeLa cells inoculated in female nu/nu mice induced a moderate increased tumor growth compared to $\mathrm{HeLa}$ mock cells, at day 47 . RCN3 has been identified as a negative regulator of collagen production in cardiac fibrosis. CRISPR/Cas9-mediated activation of RCN-3 decreased collagen production in human cardiac fibroblasts (62). In this study, down-regulation of collagen type I alpha 1 chain (COL1A1) and collagen alpha-2(I) chain (COL1A2) was observed in CC samples, compared to control. Previous studies have shown that collagen expression depends on the tumor stage. Specifically, normal breast fibroblasts in co-cultures with breast cancer cell lines derived from late-stage breast cancer 
$H \& E$
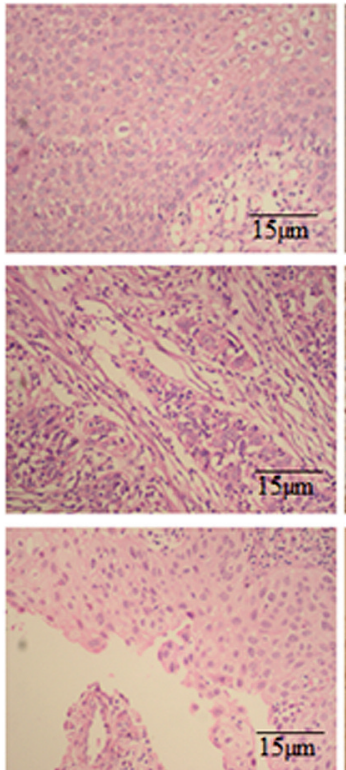

RAB14

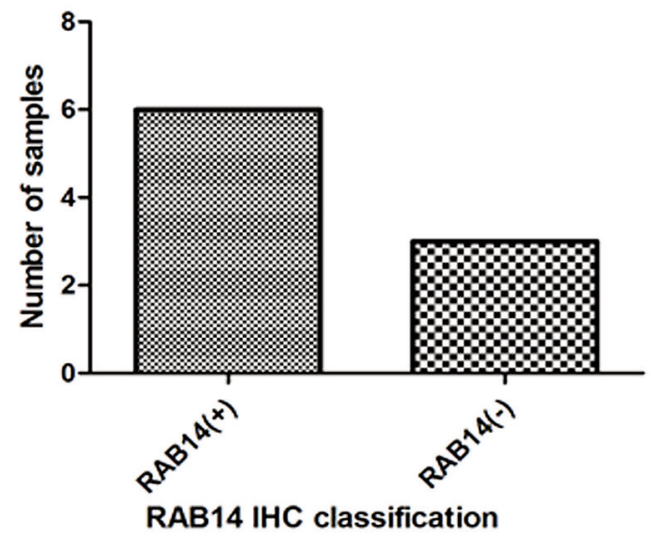

RAB14
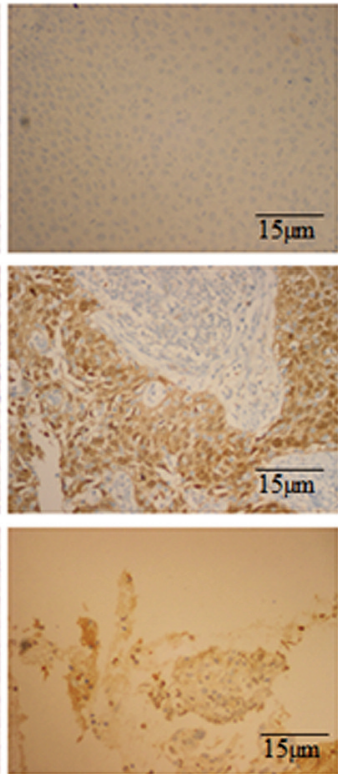

$\overline{15 \mathrm{~mm}}$
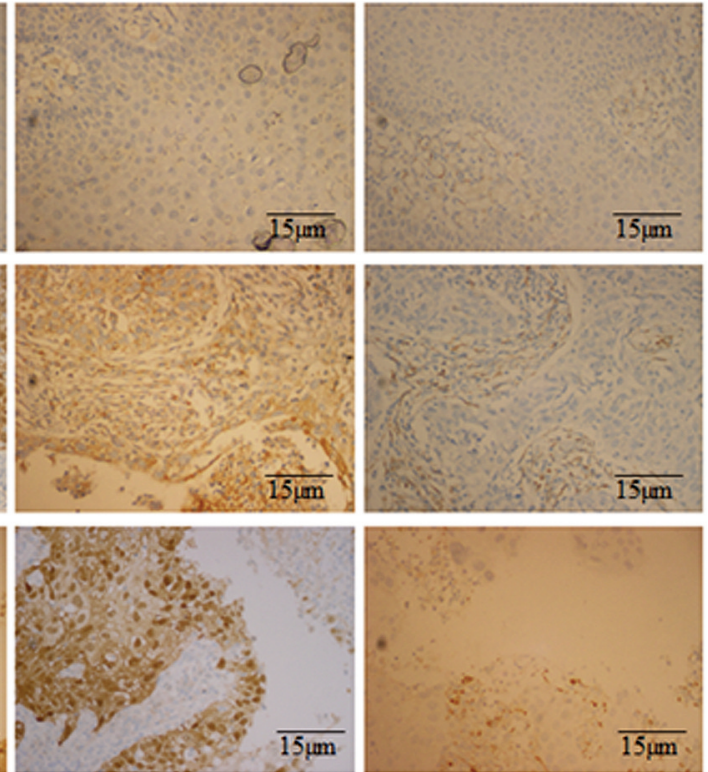

RCN3

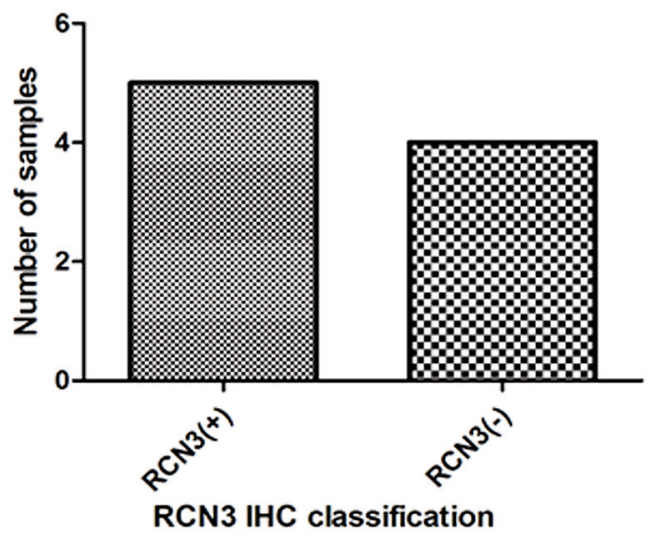

Figure 5. Immunohistochemical (IHC) assay for detection of RAB14 and RCN3 protein expression; p16 was considered positive control), RAB14 and RCN3. Six out of 9 samples were positive for RAB14 protein and 5 out of 9 slides from CC samples were positive to RCN3 protein. H\&E, Hematoxylin-eosin.

(MDA-MB-231, MCF-7, T47D, and ZR-75-1) have been shown to exhibit a greater than $50 \%$ reduction in collagen protein. Furthermore, in breast cancer tissue samples, Northern analysis has revealed that collagen mRNA levels were elevated in stage I tumors compared to adjacent normal breast tissues, while decreased in stage II and III breast tumors (87). Therefore, we suggest that RCN3 may participate as a negative regulator of collagen production in $\mathrm{CC}$ and modulates the dynamic collagen concentration from the early to late stages of tumor development. In the early stages, the collagen concentration tends to increase compared to the adjacent extracellular matrix (ECM), this protein in cancer has been studied, and evidence shows that collagen type I promotes resistance to apoptosis in fetal calf serum-starved MCF-7 and T-47D cells (88). Furthermore, E-cadherin gene expression has been found to be downregulated by collagen type I and type III in pancreatic cancer cell lines (89). In addition, pathological conditions such as cancer cell proliferation and metastatic events have been associated with defective E-cadherinmediated cell-cell adhesion (90). Therefore, RCN3 may be implicated in the modulation of collagen production and Ecadherin gene expression in CC cells.

A quarter of all proteins identified and quantified in $\mathrm{CC}$ are related to exocytosis. Recent lines of evidence support 
Table V. Common proteins between SCC and CAD.

\begin{tabular}{|c|c|c|c|c|c|c|c|c|c|c|}
\hline Number & Name & CC_CTRL $^{1}$ & $p$-Value ${ }^{2}$ & SCC_CTRL1 & $p$-Value ${ }^{2}$ & CAD_CTRL1 & $p$-Value ${ }^{2}$ & SCC_CAD1 & $p$-Value 2 & Cell function \\
\hline 1 & ICAL & 2.575 & 0.000 & 2.638 & 0.000 & 2.685 & 0.174 & -0.047 & 0.774 & $\begin{array}{l}\text { Activating invasion } \\
\text { and metastasis (55-57 }\end{array}$ \\
\hline 2 & EFHD2 & 2.190 & 0.000 & 2.342 & 0.000 & 1.916 & 0.078 & 0.426 & 0.166 & Resisting cell death (56-58) \\
\hline 3 & SAP & 2.103 & 0.001 & 2.029 & 0.007 & 2.810 & 0.019 & -0.781 & 0.002 & Resisting cell death (57-59) \\
\hline 4 & IF4H & 2.029 & 0.014 & 2.047 & 0.009 & 2.142 & 0.032 & -0.095 & 0.299 & Resisting cell death (58-61) \\
\hline 5 & ML12B & 1.971 & 0.000 & 2.103 & 0.001 & 1.993 & 0.001 & 0.110 & 0.898 & Muscle contraction \\
\hline 6 & RS28 & 2.171 & 0.000 & 2.285 & 0.000 & 1.953 & 0.072 & 0.333 & 0.325 & Cytoplasmic translation \\
\hline 7 & PRTN3 & 2.137 & 0.013 & 2.223 & 0.008 & 2.088 & 0.089 & 0.135 & 0.851 & $\begin{array}{c}\text { Antimicrobial } \\
\text { humoral response }\end{array}$ \\
\hline 8 & $\mathrm{CH} 10$ & 2.037 & 0.000 & 1.910 & 0.000 & 2.663 & 0.012 & -0.753 & 0.000 & $\begin{array}{l}\text { Activating invasion } \\
\text { and metastasis }(60-62)\end{array}$ \\
\hline 9 & $\mathrm{RCN} 3$ & 1.943 & 0.042 & 1.940 & 0.046 & 1.975 & 0.192 & -0.034 & 0.938 & $\begin{array}{l}\text { Activating invasion } \\
\text { and metastasis (61-64) }\end{array}$ \\
\hline 10 & GVIN1 & 1.919 & 0.000 & 1.974 & 0.000 & 2.039 & 0.092 & -0.065 & 0.561 & $\begin{array}{c}\text { Tumor promoting } \\
\text { inflammation }(63-65)\end{array}$ \\
\hline 11 & PERM & 2.340 & 0.005 & 2.036 & 0.020 & 3.069 & 0.020 & -1.034 & 0.018 & $\begin{array}{l}\text { Tumor promoting } \\
\text { inflammation (64-67) }\end{array}$ \\
\hline 12 & TPD54 & 2.320 & 0.000 & 2.323 & 0.000 & 2.521 & 0.090 & -0.199 & 0.397 & $\begin{array}{l}\text { Deregulating cellular } \\
\text { energetics }(66-69)\end{array}$ \\
\hline 13 & SRSF2 & 2.299 & 0.090 & 2.396 & 0.074 & 1.991 & 0.131 & 0.406 & 0.154 & mRNA processing \\
\hline 14 & HEBP2 & 2.301 & 0.001 & 2.361 & 0.002 & 2.535 & 0.012 & -0.173 & 0.197 & $\begin{array}{l}\text { negative regulation of } \\
\text { mitochondrial membrane } \\
\text { potential }\end{array}$ \\
\hline 15 & TPM3L & 2.155 & 0.000 & 2.295 & 0.000 & 1.983 & 0.048 & 0.312 & 0.262 & Actin filament organization \\
\hline 16 & ANXA3 & 2.236 & 0.011 & 2.430 & 0.007 & 1.951 & 0.059 & 0.479 & 0.201 & $\begin{array}{c}\text { Inducing angiogenesis } \\
(68-71)\end{array}$ \\
\hline 17 & MARCS & 2.795 & 0.000 & 3.010 & 0.000 & 2.296 & 0.260 & 0.714 & 0.347 & Resisting cell death (70-73) \\
\hline 18 & MIME & -2.668 & 0.288 & -2.778 & 0.283 & -2.074 & 0.284 & -0.704 & 0.695 & $\begin{array}{l}\text { Negative regulation } \\
\text { of smooth muscle cell } \\
\text { proliferation }\end{array}$ \\
\hline 19 & COEA1 & -2.670 & 0.303 & -2.704 & 0.302 & -2.624 & 0.291 & -0.079 & 0.965 & Cell-cell adhesion \\
\hline 20 & DESM & -2.558 & 0.291 & -2.456 & 0.291 & -2.595 & 0.272 & 0.139 & 0.973 & $\begin{array}{l}\text { Inducing angiogenesis } \\
\qquad(72-74)\end{array}$ \\
\hline 21 & KCRB & -2.035 & 0.000 & -1.972 & 0.000 & -2.108 & 0.071 & 0.136 & 0.893 & $\begin{array}{l}\text { Deregulating cellular } \\
\text { energetics }(73-75)\end{array}$ \\
\hline 22 & CO6A3 & -1.950 & 0.230 & -1.959 & 0.233 & -2.349 & 0.183 & 0.390 & 0.627 & Cell adhesion \\
\hline 23 & NQO1 & -2.056 & 0.076 & -1.972 & 0.074 & -2.693 & 0.075 & 0.722 & 0.040 & Cell redox homeostasis \\
\hline 24 & CO6A1 & -2.209 & 0.333 & -2.140 & 0.340 & -2.908 & 0.294 & 0.768 & 0.518 & Cell adhesion \\
\hline 25 & CO6A2 & -2.387 & 0.167 & -2.364 & 0.168 & -3.312 & 0.145 & 0.948 & 0.219 & Cell adhesion \\
\hline 26 & TGM2 & -2.501 & 0.090 & -2.201 & 0.087 & -3.232 & 0.094 & 1.032 & 0.038 & $\begin{array}{l}\text { Activating invasion } \\
\text { and metastasis (74-76) }\end{array}$ \\
\hline 27 & ALBU & -2.182 & 0.085 & -2.098 & 0.086 & -3.099 & 0.056 & 1.001 & 0.202 & $\begin{array}{l}\text { Negative regulation } \\
\text { of apoptotic process }\end{array}$ \\
\hline
\end{tabular}

${ }^{1}$ Protein expression fold-change; ${ }^{2} p$-Value according to Gene Set Enrichment Analysis. CC: Cervical cancer; SCC: squamous cervical cancer; CAD: cervical adenocarcinoma; CTRL: control.

the participation of exocytosis in the acquisition of metastatic traits and resistance to apoptosis through Ras-related protein family as endosomal recycling mediators. RAB14 belongs to a family of regulator proteins that orchestrate vesicle trafficking events, including vesicle formation, vesicle movement, and vesicle binding to their target membrane (91). RAB14 was overexpressed in SqPD16 compared to control, and 6/9 CC samples were positive to RAB 14 by
IHC. RAB14 acts as a molecular switch between inactive and active states based on its binding to guanosine diphosphate (GDP) and guanosine triphosphate (GTP), respectively, to activate downstream pathways. RAB14 is upregulated in gastric cancer tumor tissues compared to adjacent non-tumor tissues (92). At post-translational level (miRNAs), RAB protein has been suggested as an oncogene in non-small cell lung carcinoma (NSCLC) due to the 

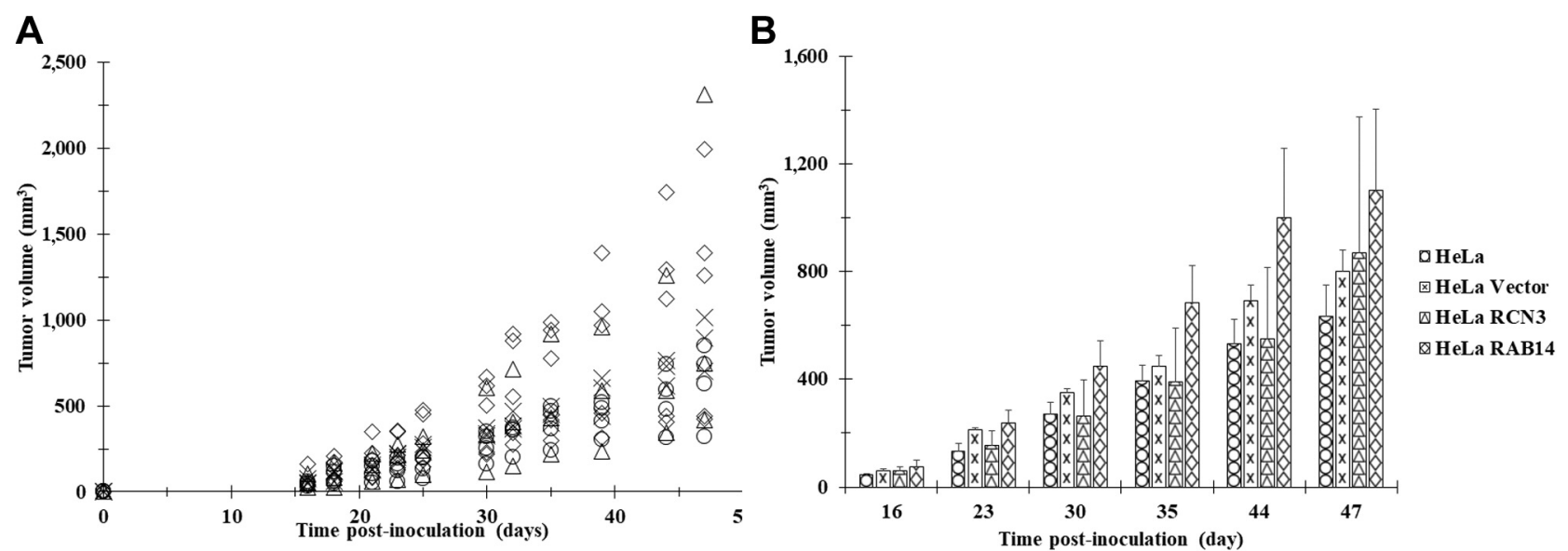

C
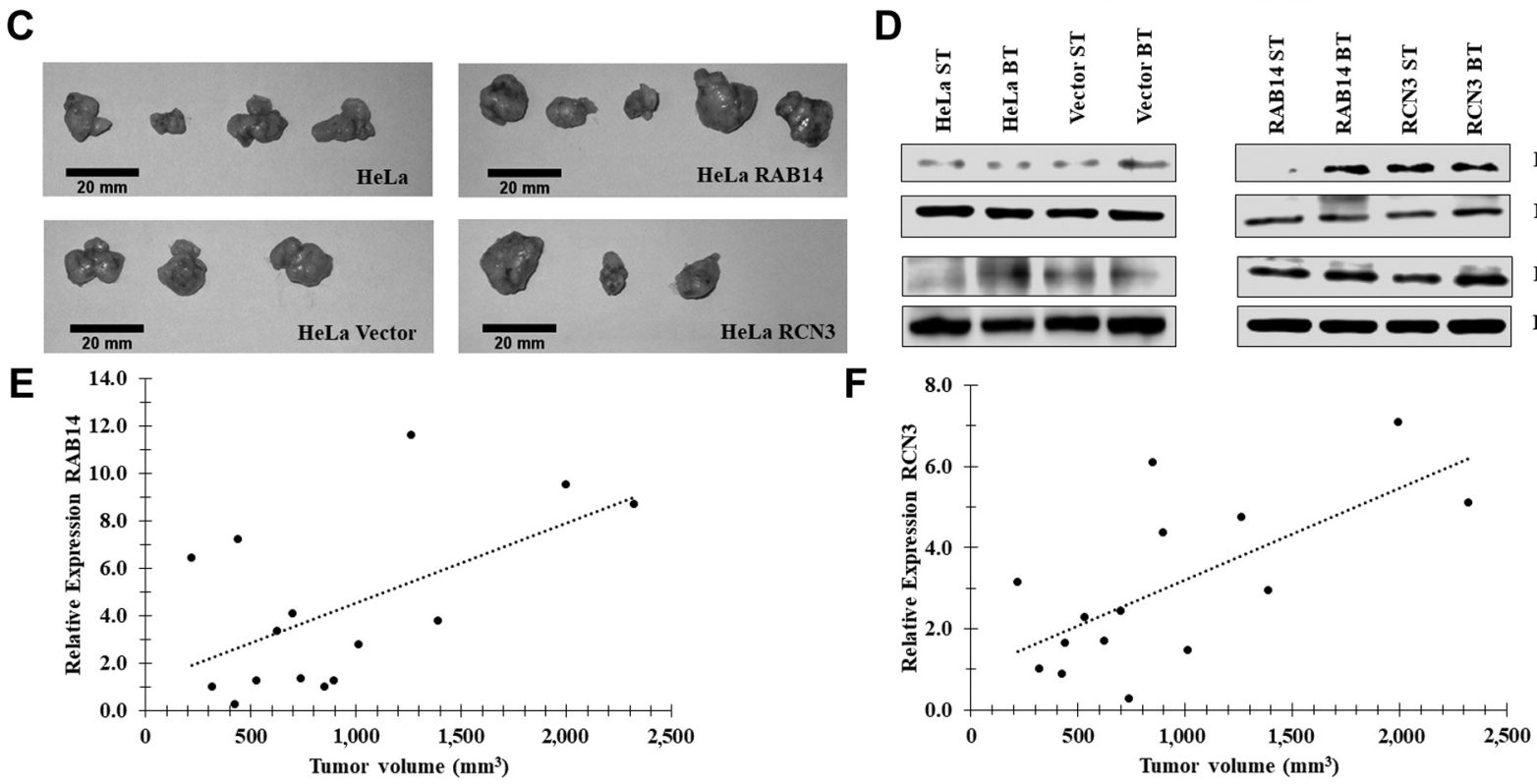

Figure 6. Tumor xenograft model: RAB14- and RCN3-overexpressing HeLa cells were separately inoculated subcutaneously into female nu/nu mice. Tumor growth curves measured for wild type, RAB14, RCN3, or vector expressing HeLa cells (A). Bar graph showing tumor volume; values are presented as mean $\pm S D(B)$. Photos of the excised tumors from each group $(C)$. The expression of RAB14 and RCN3 was analyzed by western blot assay in smallest tumor (ST) and biggest tumor obtained (BT); b-actin was used as an internal control (D). Relative protein expression of $R A B 14(E)$ and RCN3 $(F)$ was measured by western blot assay considering tumor volume; b-actin was used as internal control.

frequent loss of its negative miRNA regulators miR-451 and miR-338-3p (93, 94). Evidence provided by ectopic expression of miRNA-451 showed negative effects on in vitro proliferation and colony formation of NSCL cells and the development of tumors in nude mice by enhancing apoptosis. Ectopic expression of miR-451 inhibited RAB14 protein expression, and RAB14 restoration partially attenuated tumor suppressor function of miR-451 in NSCLC. RAB14 may be a critical regulator for cell proliferation in cancer (93). Furthermore, analyses performed on RAB14positive vesicles confirmed that 38 cargo proteins were directly involved in metastasis. It was proposed that RAB14 participates as an active metastasis mediator by facilitating endosomal recycling (95).

In our xenograft murine model, RAB14 overexpression showed a positive correlation with tumor growth. According to previous experiments in 3T3-L1 adipocytes, optimal levels of RAB14 direct the traffic of glucose by the transporter type 4 (GLUT4). This was demonstrated when depletion of endogenous RAB14 by shRNA-mediated knockdown inhibited sorting of GLUT4 to an internal compartment(s) by means of vesicles (96). GLUT4 belongs to a family of glucose transporter isoforms distributed in different organs. GLUT1 and GLUT3 are found in neurons, astrocytes, fat, and muscle tissues (97), 
GLUT2 in enterocytes, kidney, and liver cells (98). GLUT4 is found in muscle and fat cells and is responsible for $80 \%$ of glucose intake in skeletal muscle (99). RAB14 overexpression in HeLa cells suggest RAB14 may orchestrate glucose recruitment by translocation of more GLUT4 glucose transporters from intracellular compartments (Golgi membranes and endosomes) to the cell surface, thus sustaining abnormal cellular energy that contributes to tumor growth (100) as we experimentally observed. This new role for RAB14 in cervical cancer may provide a new direction in prognosis or therapy.

\section{Conclusion}

RAB14 and RCN3 were indicated as potential biomarkers and therapeutic targets in CC. SCC and CAD proteomic profiles offer valuable information that may serve to identify novel biomarkers associated with disease prognosis and new potential therapeutic targets for the treatment of CC.

\section{Supplementary Material}

Supplemental Figure 1, Supplemental Tables I, II, and III can be consulted in the following link: http://sinik.ccg.unam.mx/PGFP/ Ramirez.AR2021.No399-R/

\section{Conflicts of Interest}

The Authors declare that the research was carried out in the absence of any commercial or financial relationship that could potentially be considered as conflicts of interest.

\section{Authors' Contributions}

SEG conceptualized the research. ART, JG, AGC and SEG conceived and designed the experiments. ART, SC, JG, GR, and HAVG performed the experiments. ART, LGC and ESB analyzed the data. SEG and AGC contributed resources and equipment. ART and SEG wrote the paper. All Authors read and approved the final manuscript.

\section{Acknowledgements}

Alberto Ramírez-Torres is a doctoral student from Programa de Doctorado en Ciencias Biomédicas, Universidad Nacional Autónoma de México (UNAM) and received the fellowship 255711 from CONACYT. We also thank Alejandro Aguilar Vera for his support in the statistical analysis, Michael F. Dunn for critical reading and language editing, and the Unidad de Modelos Biológicos IIB-UNAM for their support in production and handling the laboratory animals.

\section{Funding}

Part of this work was supported by DGAPA-PAPIIT grant IN207519.

\section{Availability of Data and Materials}

The datasets used and/or analyzed during the current study are available from the corresponding author on reasonable request.

\section{References}

1 Torre LA, Bray F, Siegel RL, Ferlay J, Lortet-Tieulent J and Jemal A: Global cancer statistics, 2012. CA Cancer J Clin 65(2): 87-108, 2015. PMID: 25651787. DOI: 10.3322/caac.21262

2 Safaeian M, Solomon D and Castle PE: Cervical cancer prevention - cervical screening: science in evolution. Obstet Gynecol Clin North Am 34(4): 739-60, ix, 2007. PMID: 18061867. DOI: 10.1016/j.ogc.2007.09.004

3 Bosch FX, Broker TR, Forman D, Moscicki AB, Gillison ML, Doorbar J, Stern PL, Stanley M, Arbyn M, Poljak M, Cuzick J, Castle PE, Schiller JT, Markowitz LE, Fisher WA, Canfell K, Denny LA, Franco EL, Steben M, Kane MA, Schiffman M, Meijer CJ, Sankaranarayanan R, Castellsagué X, Kim JJ, Brotons M, Alemany L, Albero G, Diaz M, de Sanjosé S and authors of ICO Monograph Comprehensive Control of HPV Infections and Related Diseases Vaccine: Comprehensive control of human papillomavirus infections and related diseases. Vaccine 31(Suppl 7): H1-31, 2013. PMID: 24332295. DOI: 10.1016/j.vaccine. 2013.10.003

4 Lee YY, Choi CH, Kim TJ, Lee JW, Kim BG, Lee JH and Bae DS: A comparison of pure adenocarcinoma and squamous cell carcinoma of the cervix after radical hysterectomy in stage IBIIA. Gynecol Oncol 120(3): 439-443, 2011. PMID: 21145099. DOI: $10.1016 /$ j.ygyno.2010.11.022

5 Katanyoo K, Sanguanrungsirikul S and Manusirivithaya S: Comparison of treatment outcomes between squamous cell carcinoma and adenocarcinoma in locally advanced cervical cancer. Gynecol Oncol 125(2): 292-296, 2012. PMID: 22293041. DOI: 10.1016/j.ygyno.2012.01.034

6 International Collaboration of Epidemiological Studies of Cervical Cancer: Comparison of risk factors for invasive squamous cell carcinoma and adenocarcinoma of the cervix: collaborative reanalysis of individual data on 8,097 women with squamous cell carcinoma and 1,374 women with adenocarcinoma from 12 epidemiological studies. Int J Cancer 120(4): 885-891, 2007. PMID: 17131323. DOI: 10.1002/ijc.22357

7 Smith HO, Tiffany MF, Qualls CR and Key CR: The rising incidence of adenocarcinoma relative to squamous cell carcinoma of the uterine cervix in the United States - a 24-year population-based study. Gynecol Oncol 78(2): 97-105, 2000. PMID: 10926787. DOI: 10.1006/gyno.2000.5826

8 Molijn A, Jenkins D, Chen W, Zhang X, Pirog E, Enqi W, Liu B, Schmidt J, Cui J, Qiao Y, Quint W and Chinese HPV Typing Group: The complex relationship between human papillomavirus and cervical adenocarcinoma. Int J Cancer 138(2): 409-416, 2016. PMID: 26334557. DOI: 10.1002/ijc.29722

9 An HJ, Kim KR, Kim IS, Kim DW, Park MH, Park IA, Suh KS, Seo EJ, Sung SH, Sohn JH, Yoon HK, Chang ED, Cho HI, Han JY, Hong SR and Ahn GH: Prevalence of human papillomavirus DNA in various histological subtypes of cervical adenocarcinoma: a population-based study. Mod Pathol 18(4): 528-534, 2005. PMID: 15502807. DOI: 10.1038/modpathol.3800316

10 Berrington de González A, Sweetland S and Green J: Comparison of risk factors for squamous cell and adenocarcinomas of the 
cervix: a meta-analysis. Br J Cancer 90(9): 1787-1791, 2004 PMID: 15150591. DOI: 10.1038/sj.bjc.6601764

11 Qu W, Jiang G, Cruz Y, Chang CJ, Ho GY, Klein RS and Burk RD: PCR detection of human papillomavirus: comparison between MY09/MY11 and GP5+/GP6+ primer systems. J Clin Microbiol 35(6): 1304-1310, 1997. PMID: 9163434. DOI: 10.1128/jcm.35.6.1304-1310.1997

12 Shruthi BS, Vinodhkumar P and Selvamani: Proteomics: A new perspective for cancer. Adv Biomed Res 5: 67, 2016. PMID: 27169098. DOI: $10.4103 / 2277-9175.180636$

13 Solomon D: The Bethesda System for reporting cervical/vaginal cytologic diagnosis: an overview. Int J Gynecol Pathol 10(4): 323325, 1991. PMID: 1774102. DOI: 10.1097/00004347-19911000000003

14 Kruger NJ: The Bradford method for protein quantitation. Methods Mol Biol 32: 9-15, 1994. PMID: 7951753. DOI: 10.1385/0-89603-268-X:9

15 Stekhoven DJ and Bühlmann P: MissForest-non-parametric missing value imputation for mixed-type data. Bioinformatics 28(1): 112-118, 2012. PMID: 22039212. DOI: 10.1093/ bioinformatics/btr597

16 Lê S, Josse J and Husson F: Factominer: An R package for multivariate analysis. J Stat Softw 25(1): 1-18, 2008. DOI: 10.18637/jss.v025.i01

17 Petrak J, Ivanek R, Toman O, Cmejla R, Cmejlova J, Vyoral D, Zivny $\mathrm{J}$ and Vulpe $\mathrm{CD}$ : Déjà vu in proteomics. A hit parade of repeatedly identified differentially expressed proteins Proteomics 8(9): 1744-1749, 2008. PMID: 18442176. DOI: 10.1002/pmic.200700919

18 Abdi H and Williams L: Principal component analysis. Wiley Interdisciplinary Reviews: Computational Statistics 2(4): $433-$ 459, 2021. DOI: 10.1002/wics.101

19 Lever J, Krzywinski M and Altman N: Principal component analysis. Nature Methods 14(7): 641-642, 2021. DOI: 10.1038/nmeth.4346

20 Wang M, Zhao Y and Zhang B: Efficient test and visualization of multi-set intersections. Sci Rep 5: 16923, 2015. PMID: 26603754. DOI: 10.1038/srep16923

21 Subramanian A, Tamayo P, Mootha VK, Mukherjee S, Ebert BL, Gillette MA, Paulovich A, Pomeroy SL, Golub TR, Lander ES and Mesirov JP: Gene set enrichment analysis: a knowledgebased approach for interpreting genome-wide expression profiles. Proc Natl Acad Sci USA 102(43): 15545-15550, 2005. PMID: 16199517. DOI: 10.1073/pnas.0506580102

22 Kitazawa S, Takaoka Y, Ueda Y and Kitazawa R: Identification of calmodulin-like protein 5 as tumor-suppressor gene silenced during early stage of carcinogenesis in squamous cell carcinoma of uterine cervix. Int J Cancer 149(6): 1358-1368, 2021. PMID: 33997976. DOI: 10.1002/ijc.33687

23 Shao S, Fan Y, Zhong C, Zhu X and Zhu J: Coactosin-like protein (COTL1) promotes glioblastoma (GBM) growth in vitro and in vivo. Cancer Manag Res 12: 10909-10917, 2020. PMID: 33154670. DOI: 10.2147/CMAR.S246030

24 Liu J, Cao S, Ding G, Wang B, Li Y, Zhao Y, Shao Q, Feng J, Liu S, Qin L and Xiao Y: The role of 14-3-3 proteins in cell signalling pathways and virus infection. J Cell Mol Med 25(9): 4173-4182, 2021. PMID: 33793048. DOI: 10.1111/jcmm.16490

25 Vanaja DK, Cheville JC, Iturria SJ and Young CY: Transcriptional silencing of zinc finger protein 185 identified by expression profiling is associated with prostate cancer progression. Cancer Res 63(14): 3877-3882, 2003. PMID: 12873976.
26 Sakkal S, Miller S, Apostolopoulos V and Nurgali K: Eosinophils in cancer: favourable or unfavourable? Curr Med Chem 23(7): 650-666, 2016. PMID: 26785997. DOI: 10.2174/0929867323666160119094313

27 Qi Y and Xu R: Roles of PLODs in collagen synthesis and cancer progression. Front Cell Dev Biol 6: 66, 2018. PMID: 30003082. DOI: 10.3389/fcell.2018.00066

28 Wang X, Yang J, Qian J, Liu Z, Chen H and Cui Z: S100A14, a mediator of epithelial-mesenchymal transition, regulates proliferation, migration and invasion of human cervical cancer cells. Am J Cancer Res 5(4): 1484-1495, 2015. PMID: 26101712.

29 Han W, Hu C, Fan ZJ and Shen GL: Transcript levels of keratin $1 / 5 / 6 / 14 / 15 / 16 / 17$ as potential prognostic indicators in melanoma patients. Sci Rep 11(1): 1023, 2021. PMID: 33441834. DOI: 10.1038/s41598-020-80336-8

30 Bandaru S, Zhou AX, Rouhi P, Zhang Y, Bergo MO, Cao Y and Akyürek LM: Targeting filamin B induces tumor growth and metastasis via enhanced activity of matrix metalloproteinase-9 and secretion of VEGF-A. Oncogenesis 3: e119, 2014. PMID: 25244493. DOI: 10.1038 /oncsis.2014.33

31 Zhang X, Su L and Sun K: Expression status and prognostic value of the perilipin family of genes in breast cancer. Am J Transl Res 13(5): 4450-4463, 2021. PMID: 34150026.

32 Li D, Chen Y, Mei H, Jiao W, Song H, Ye L, Fang E, Wang X, Yang F, Huang K, Zheng L and Tong Q: Ets-1 promoterassociated noncoding RNA regulates the NONO/ERG/Ets- 1 axis to drive gastric cancer progression. Oncogene 37(35): 4871-4886, 2018. PMID: 29773901. DOI: 10.1038/s41388-018-0302-4

33 Kim SJ, Ju JS, Kang MH, Eun JW, Kim YH, Raninga PV, Khanna KK, Győrffy B, Pack CG, Han HD, Lee HJ, Gong G, Shin Y, Mills GB, Eyun SI and Park YY: RNA-binding protein NONO contributes to cancer cell growth and confers drug resistance as a theranostic target in TNBC. Theranostics 10(18): 7974-7992, 2020. PMID: 32724453. DOI: $10.7150 /$ thno .45037

34 Morozov AV and Karpov VL: Proteasomes and several aspects of their heterogeneity relevant to cancer. Front Oncol 9: 761, 2019. PMID: 31456945. DOI: 10.3389/fonc.2019.00761

35 Zhang $\mathrm{Y}$ and Zhang L: Knockdown of LASP2 inhibits the proliferation, migration, and invasion of cervical cancer cells. J Cell Biochem 120(9): 15389-15396, 2019. PMID: 31026088. DOI: $10.1002 /$ jcb.28806

36 Hage-Sleiman R, Herveau S, Matera EL, Laurier JF and Dumontet C: Tubulin binding cofactor C (TBCC) suppresses tumor growth and enhances chemosensitivity in human breast cancer cells. BMC Cancer 10: 135, 2010. PMID: 20384997. DOI: $10.1186 / 1471-2407-10-135$

37 Pang T, Li M, Zhang Y, Yong W, Kang H, Yao Y and Hu X: Y Boxbinding protein 1 promotes epithelial-mesenchymal transition, invasion, and metastasis of cervical cancer via enhancing the expressions of snail. Int J Gynecol Cancer 27(8): 1753-1760, 2017. PMID: 28708785. DOI: 10.1097/IGC.0000000000001066

38 Zhao C, Lu E, Hu X, Cheng H, Zhang JA and Zhu X: S100A9 regulates cisplatin chemosensitivity of squamous cervical cancer cells and related mechanism. Cancer Manag Res 10: 3753-3764, 2018. PMID: 30288106. DOI: 10.2147/CMAR.S168276

39 Zhu J, Zhao R, Xu W, Ma J, Ning X, Ma R and Meng F: Correlation between reticulum ribosome-binding protein 1 (RRBP1) overexpression and prognosis in cervical squamous cell carcinoma. Biosci Trends 14(4): 279-284, 2020. PMID: 32536673. DOI: $10.5582 /$ bst.2020.03136 
40 Tsai HY, Yang YF, Wu AT, Yang CJ, Liu YP, Jan YH, Lee CH, Hsiao YW, Yeh CT, Shen CN, Lu PJ, Huang MS and Hsiao M: Endoplasmic reticulum ribosome-binding protein 1 (RRBP1) overexpression is frequently found in lung cancer patients and alleviates intracellular stress-induced apoptosis through the enhancement of GRP78. Oncogene 32(41): 4921-4931, 2013. PMID: 23318453. DOI: 10.1038/onc.2012.514

41 Hua X, Zhang H, Jia J, Chen S, Sun Y and Zhu X: Roles of S100 family members in drug resistance in tumors: Status and prospects. Biomed Pharmacother 127: 110156, 2020. PMID: 32335300. DOI: 10.1016/j.biopha.2020.110156

42 Banáth JP, Macphail SH and Olive PL: Radiation sensitivity, H2AX phosphorylation, and kinetics of repair of DNA strand breaks in irradiated cervical cancer cell lines. Cancer Res 64(19): 7144-7149, 2004. PMID: 15466212. DOI: 10.1158/00085472.CAN-04-1433

43 Weyemi U, Redon CE, Choudhuri R, Aziz T, Maeda D, Boufraqech M, Parekh PR, Sethi TK, Kasoji M, Abrams N, Merchant A, Rajapakse VN and Bonner WM: The histone variant H2A.X is a regulator of the epithelial-mesenchymal transition. Nat Commun 7: 10711, 2016. PMID: 26876487. DOI: 10.1038/ncomms 10711

44 Gebauer F, Wicklein D, Horst J, Sundermann P, Maar H, Streichert T, Tachezy M, Izbicki JR, Bockhorn M and Schumacher U: Carcinoembryonic antigen-related cell adhesion molecules (CEACAM) 1, 5 and 6 as biomarkers in pancreatic cancer. PLoS One 9(11): e113023, 2014. PMID: 25409014. DOI: 10.1371/journal.pone. 0113023

45 Jain S, Russell S and Ware J: Platelet glycoprotein VI facilitates experimental lung metastasis in syngenic mouse models. J Thromb Haemost 7(10): 1713-1717, 2009. PMID: 19624454. DOI: $10.1111 / \mathrm{j} .1538-7836.2009 .03559 . x$

46 Herrmann PC, Gillespie JW, Charboneau L, Bichsel VE, Paweletz CP, Calvert VS, Kohn EC, Emmert-Buck MR, Liotta LA and Petricoin EF 3rd: Mitochondrial proteome: altered cytochrome c oxidase subunit levels in prostate cancer. Proteomics 3(9): 1801-1810, 2003. PMID: 12973739. DOI: 10.1002/pmic.200300461

47 Nipp M, Elsner M, Balluff B, Meding S, Sarioglu H, Ueffing M, Rauser S, Unger K, Höfler H, Walch A and Zitzelsberger H: S100-A10, thioredoxin, and S100-A6 as biomarkers of papillary thyroid carcinoma with lymph node metastasis identified by MALDI imaging. J Mol Med (Berl) 90(2): 163-174, 2012. PMID: 21938494. DOI: 10.1007/s00109-011-0815-6

48 Jaillon S, Ponzetta A, Di Mitri D, Santoni A, Bonecchi R and Mantovani A: Neutrophil diversity and plasticity in tumour progression and therapy. Nat Rev Cancer 20(9): 485-503, 2020. PMID: 32694624. DOI: 10.1038/s41568-020-0281-y

49 Sato T, Takahashi S, Mizumoto T, Harao M, Akizuki M, Takasugi M, Fukutomi T and Yamashita J: Neutrophil elastase and cancer. Surg Oncol 15(4): 217-222, 2006. PMID: 17320378. DOI: $10.1016 /$ j.suronc.2007.01.003

50 Zhao L, Xu S, Fjaertoft G, Pauksen K, Håkansson L and Venge P: An enzyme-linked immunosorbent assay for human carcinoembryonic antigen-related cell adhesion molecule 8 , a biological marker of granulocyte activities in vivo. J Immunol Methods 293(1-2): 207-214, 2004. PMID: 15541289. DOI: 10.1016/j.jim.2004.08.009

51 Vaughn AE and Deshmukh M: Glucose metabolism inhibits apoptosis in neurons and cancer cells by redox inactivation of cytochrome c. Nat Cell Biol 10(12): 1477-1483, 2008. PMID: 19029908. DOI: $10.1038 / \mathrm{ncb} 1807$

52 Fillies T, Werkmeister R, Packeisen J, Brandt B, Morin P, Weingart D, Joos U and Buerger H: Cytokeratin 8/18 expression indicates a poor prognosis in squamous cell carcinomas of the oral cavity. BMC Cancer 6: 10, 2006. PMID: 16412231. DOI: 10.1186/1471-2407-6-10

53 Minns D, Smith KJ, Alessandrini V, Hardisty G, Melrose L, Jackson-Jones L, MacDonald AS, Davidson DJ and Gwyer Findlay E: The neutrophil antimicrobial peptide cathelicidin promotes Th17 differentiation. Nat Commun 12(1): 1285, 2021. PMID: 33627652. DOI: 10.1038/s41467-021-21533-5

54 Madanchi H, Shoushtari M, Kashani HH and Sardari S: Antimicrobial peptides of the vaginal innate immunity and their role in the fight against sexually transmitted diseases. New Microbes New Infect 34: 100627, 2019. PMID: 31993204. DOI: 10.1016/j.nmni.2019.100627

55 Ma Y, Chen Y, Li Y, Grün K, Berndt A, Zhou Z and Petersen I: Cystatin A suppresses tumor cell growth through inhibiting epithelial to mesenchymal transition in human lung cancer. Oncotarget 9(18): 14084-14098, 2017. PMID: 29581829. DOI: 10.18632/oncotarget.23505

56 Zhang S, Deen S, Storr SJ, Chondrou PS, Nicholls H, Yao A, Rungsakaolert $\mathrm{P}$ and Martin SG: Calpain system protein expression and activity in ovarian cancer. J Cancer Res Clin Oncol 145(2): 345-361, 2019. PMID: 30448882. DOI: 10.1007/s00432-018-2794-2

57 Thylur RP, Gowda R, Mishra S and Jun CD: Swiprosin-1: Its expression and diverse biological functions. J Cell Biochem 119(1): 150-156, 2018. PMID: 28590012. DOI: 10.1002/jcb.26199

58 Lee TJ, Sartor O, Luftig RB and Koochekpour S: Saposin C promotes survival and prevents apoptosis via PI3K/Aktdependent pathway in prostate cancer cells. Mol Cancer 3: 31, 2004. PMID: 15548330. DOI: 10.1186/1476-4598-3-31

59 Bitterman PB and Polunovsky VA: eIF4E-mediated translational control of cancer incidence. Biochim Biophys Acta 1849(7): 774780, 2015. PMID: 25263391. DOI: 10.1016/j.bbagrm.2014.09.007

60 Vaysse C, Philippe C, Martineau Y, Quelen C, Hieblot C, Renaud C, Nicaise Y, Desquesnes A, Pannese M, Filleron T, Escourrou G, Lawson M, Rintoul RC, Delisle MB, Pyronnet S, Brousset P, Prats $\mathrm{H}$ and Touriol C: Key contribution of eIF4H-mediated translational control in tumor promotion. Oncotarget 6(37): 39924-39940, 2015. PMID: 26498689. DOI: 10.18632/oncotarget.5442

61 Cappello F, Bellafiore M, David S, Anzalone R and Zummo G: Ten kilodalton heat shock protein (HSP10) is overexpressed during carcinogenesis of large bowel and uterine exocervix. Cancer Lett 196(1): 35-41, 2003. PMID: 12860287. DOI: 10.1016/s0304-3835(03)00212-x

62 Martínez-Martínez E, Ibarrola J, Fernández-Celis A, Santamaria E, Fernández-Irigoyen J, Rossignol P, Jaisser F and LópezAndrés N: Differential proteomics identifies reticulocalbin-3 as a novel negative mediator of collagen production in human cardiac fibroblasts. Sci Rep 7(1): 12192, 2017. PMID: 28939891. DOI: 10.1038/s41598-017-12305-7

63 Tsuji A, Kikuchi Y, Sato Y, Koide S, Yuasa K, Nagahama M and Matsuda Y: A proteomic approach reveals transient association of reticulocalbin-3, a novel member of the CREC family, with the precursor of subtilisin-like proprotein convertase, PACE4. Biochem J 396(1): 51-59, 2006. PMID: 16433634. DOI: 10.1042/BJ20051524 
64 Pierangeli A, Degener AM, Ferreri ML, Riva E, Rizzo B, Turriziani $\mathrm{O}$, Luciani S, Scagnolari C and Antonelli G: Interferon-induced gene expression in cervical mucosa during human papillomavirus infection. Int J Immunopathol Pharmacol 24(1): 217-223, 2011 PMID: 21496405. DOI: 10.1177/039463201102400126

65 Preci DP, Almeida A, Weiler AL, Mukai Franciosi ML and Cardoso AM: Oxidative damage and antioxidants in cervical cancer. Int J Gynecol Cancer 31(2): 265-271, 2021. PMID: 33109527. DOI: 10.1136/ijgc-2020-001587

66 Lages EL, Belo AV, Andrade SP, Rocha MÂ, de Freitas GF, Lamaita RM, Traiman P and Silva-Filho AL: Analysis of systemic inflammatory response in the carcinogenic process of uterine cervical neoplasia. Biomed Pharmacother 65(7): 496-499, 2011 PMID: 22004597. DOI: 10.1016/j.biopha.2011.06.010

67 Zhuang Y, Ly RC, Frazier CV, Yu J, Qin S, Fan XY, Goetz MP, Boughey JC, Weinshilboum R and Wang L: The novel function of tumor protein D54 in regulating pyruvate dehydrogenase and metformin cytotoxicity in breast cancer. Cancer Metab 7: 1, 2019. PMID: 30697423. DOI: 10.1186/s40170-018-0193-4

68 Ren L, Chen J and Zhang X: Increased expression of tumor protein D54 is associated with clinical progression and poor prognosis in patients with prostate cancer. Oncol Lett 14(6): 7739-7744, 2017. PMID: 29250174. DOI: 10.3892/ol.2017.7214

69 Santin AD, Zhan F, Bignotti E, Siegel ER, Cané S, Bellone S, Palmieri M, Anfossi S, Thomas M, Burnett A, Kay HH, Roman JJ, O’Brien TJ, Tian E, Cannon MJ, Shaughnessy J Jr and Pecorelli S: Gene expression profiles of primary HPV16and HPV18-infected early stage cervical cancers and normal cervical epithelium: identification of novel candidate molecular markers for cervical cancer diagnosis and therapy. Virology 331(2): 269-291, 2005. PMID: 15629771. DOI: 10.1016/j.virol.2004.09.045

70 Meadows SM and Cleaver O: Annexin A3 regulates early blood vessel formation. PLoS One 10(7): e0132580, 2015. PMID: 26182056. DOI: 10.1371/journal.pone.0132580

$71 \mathrm{Li}$ Y, Gao M, Xu LN, Yin LH, Qi Y and Peng JY: MicroRNA$142-3 p$ attenuates hepatic ischemia/reperfusion injury via targeting of myristoylated alanine-rich C-kinase substrate. Pharmacol Res 156: 104783, 2020. PMID: 32224251. DOI: 10.1016/j.phrs.2020.104783

72 Iyer DN, Faruq O, Zhang L, Rastgoo N, Liu A and Chang H: Pathophysiological roles of myristoylated alanine-rich C-kinase substrate (MARCKS) in hematological malignancies. Biomark Res 9(1): 34, 2021. PMID: 33958003. DOI: 10.1186/s40364021-00286-9

73 Wu MP, Young MJ, Tzeng CC, Tzeng CR, Huang KF, Wu LW and Chou CY: A novel role of thrombospondin-1 in cervical carcinogenesis: inhibit stroma reaction by inhibiting activated fibroblasts from invading cancer. Carcinogenesis 29(6): 11151123, 2008. PMID: 18413367. DOI: 10.1093/carcin/bgn077

74 Mooney SM, Rajagopalan K, Williams BH, Zeng Y, Christudass CS, Li Y, Yin B, Kulkarni P and Getzenberg RH: Creatine kinase brain overexpression protects colorectal cells from various metabolic and non-metabolic stresses. J Cell Biochem 112(4): 1066-1075, 2011. PMID: 21308735. DOI: 10.1002/jcb.23020

75 Caffarel MM, Chattopadhyay A, Araujo AM, Bauer J, Scarpini $\mathrm{CG}$ and Coleman N: Tissue transglutaminase mediates the promalignant effects of oncostatin $\mathrm{M}$ receptor over-expression in cervical squamous cell carcinoma. J Pathol 231(2): 168-179, 2013. PMID: 23765377. DOI: 10.1002/path.4222
76 Jung EJ, Byun JM, Kim YN, Lee KB, Sung MS, Kim KT and Jeong DH: Cervical adenocarcinoma has a poorer prognosis and a higher propensity for distant recurrence than squamous cell carcinoma. Int J Gynecol Cancer 27(6): 1228-1236, 2017. PMID: 28604449. DOI: 10.1097/IGC.0000000000001009

77 Nusinow DP, Szpyt J, Ghandi M, Rose CM, McDonald ER 3rd, Kalocsay M, Jané-Valbuena J, Gelfand E, Schweppe DK, Jedrychowski M, Golji J, Porter DA, Rejtar T, Wang YK, Kryukov GV, Stegmeier F, Erickson BK, Garraway LA, Sellers WR and Gygi SP: Quantitative proteomics of the cancer cell line encyclopedia. Cell 180(2): 387-402.e16, 2020. PMID: 31978347. DOI: 10.1016/j.cell.2019.12.023

78 Lanzetti L and Di Fiore PP: Behind the scenes: Endo/exocytosis in the acquisition of metastatic traits. Cancer Res 77(8): 1813-1817, 2017. PMID: 28373181. DOI: 10.1158/0008-5472.CAN-16-3403

79 Li T, Wang Q, Hong X, Li H, Yang K, Li J and Lei B: RRBP1 is highly expressed in prostate cancer and correlates with prognosis. Cancer Manag Res 11: 3021-3027, 2019. PMID: 31118771. DOI: 10.2147/CMAR.S186632

80 Ma J, Ren S, Ding J, Liu S, Zhu J, Ma R and Meng F: Expression of RRBP1 in epithelial ovarian cancer and its clinical significance. Biosci Rep 39(7): BSR20190656, 2019. PMID: 31285390. DOI: 10.1042/BSR20190656

81 Fukuda T, Oyamada H, Isshiki T, Maeda M, Kusakabe T, Hozumi A, Yamaguchi T, Igarashi T, Hasegawa H, Seidoh T and Suzuki $\mathrm{T}$ : Distribution and variable expression of secretory pathway protein reticulocalbin in normal human organs and non-neoplastic pathological conditions. J Histochem Cytochem 55(4): 335-345, 2007. PMID: 17189526. DOI: 10.1369/jhc.6A6943.2006

82 Cooper CR, Graves B, Pruitt F, Chaib H, Lynch JE, Cox AK, Sequeria L, van Golen KL, Evans A, Czymmek K, Bullard RS, Donald CD, Sol-Church K, Gendernalik JD, Weksler B, FarachCarson MC, Macoska JA, Sikes RA and Pienta KJ: Novel surface expression of reticulocalbin 1 on bone endothelial cells and human prostate cancer cells is regulated by TNF-alpha. J Cell Biochem 104(6): 2298-2309, 2008. PMID: 18561328. DOI: $10.1002 /$ jcb. 21785

83 Liu Z, Brattain MG and Appert H: Differential display of reticulocalbin in the highly invasive cell line, MDA-MB-435, versus the poorly invasive cell line, MCF-7. Biochem Biophys Res Commun 231(2): 283-289, 1997. PMID: 9070264. DOI: 10.1006/bbrc.1997.6083

84 Giribaldi G, Barbero G, Mandili G, Daniele L, Khadjavi A, Notarpietro A, Ulliers D, Prato M, Minero VG, Battaglia A, Allasia M, Bosio A, Sapino A, Gontero P, Frea B, Fontana D and Destefanis P: Proteomic identification of Reticulocalbin 1 as potential tumor marker in renal cell carcinoma. J Proteomics 91: 385-392, 2013. PMID: 23916412. DOI: 10.1016/j.jprot.2013.07.018

85 Furue M: Epithelial tumor, invasion and stroma. Ann Dermatol 23(2): 125-131, 2011. PMID: 21747608. DOI: 10.5021/ad.2011. 23.2.125

86 Ding D, Huang H, Jiang W, Yu W, Zhu H, Liu J, Saiyin H, Wu J, Huang H, Jiang S and Yu L: Reticulocalbin-2 enhances hepatocellular carcinoma proliferation via modulating the EGFR-ERK pathway. Oncogene 36(48): 6691-6700, 2017. PMID: 28745317. DOI: 10.1038/onc.2017.230

87 Fenhalls G, Geyp M, Dent DM and Parker MI: Breast tumour cell-induced down-regulation of type I collagen mRNA in fibroblasts. $\mathrm{Br}$ J Cancer 81(7): 1142-1149, 1999. PMID: 10584874. DOI: $10.1038 /$ sj.bjc 6690821 
88 Badaoui M, Mimsy-Julienne C, Saby C, Van Gulick L, Peretti M, Jeannesson P, Morjani $\mathrm{H}$ and Ouadid-Ahidouch $\mathrm{H}$ : Collagen type 1 promotes survival of human breast cancer cells by overexpressing Kv10.1 potassium and Orail calcium channels through DDR1-dependent pathway. Oncotarget 9(37): 2465324671, 2017. PMID: 29872495. DOI: 10.18632/oncotarget.19065

89 Menke A, Philippi C, Vogelmann R, Seidel B, Lutz MP, Adler G and Wedlich D: Down-regulation of E-cadherin gene expression by collagen type I and type III in pancreatic cancer cell lines. Cancer Res 61(8): 3508-3517, 2001. PMID: 11309315.

90 Van Aken E, De Wever O, Correia da Rocha AS and Mareel M: Defective E-cadherin/catenin complexes in human cancer. Virchows Arch 439(6): 725-751, 2001. PMID: 11787845. DOI: $10.1007 / \mathrm{s} 004280100516$

91 Zerial $\mathrm{M}$ and McBride $\mathrm{H}$ : Rab proteins as membrane organizers. Nat Rev Mol Cell Biol 2(2): 107-117, 2001. PMID: 11252952. DOI: $10.1038 / 35052055$

92 Guo B, Wang W, Zhao Z, Li Q, Zhou K, Zhao L, Wang L, Yang $\mathrm{J}$ and Huang C: Rab14 act as oncogene and induce proliferation of gastric cancer cells via AKT signaling pathway. PLoS One 12(1): e0170620, 2017. PMID: 28107526. DOI: 10.1371/journal. pone. 0170620

93 Wang R, Wang ZX, Yang JS, Pan X, De W and Chen LB: MicroRNA-451 functions as a tumor suppressor in human nonsmall cell lung cancer by targeting ras-related protein 14 (RAB14). Oncogene 30(23): 2644-2658, 2011. PMID: 21358675. DOI: $10.1038 /$ onc. 2010.642

94 Sun J, Feng X, Gao S and Xiao Z: microRNA-338-3p functions as a tumor suppressor in human non small cell lung carcinoma and targets Ras-related protein 14. Mol Med Rep 11(2): 14001406, 2015. PMID: 25374067. DOI: 10.3892/mmr.2014.2880
95 Junutula JR, De Maziére AM, Peden AA, Ervin KE, Advani RJ, van Dijk SM, Klumperman $\mathrm{J}$ and Scheller RH: Rab14 is involved in membrane trafficking between the Golgi complex and endosomes. Mol Biol Cell 15(5): 2218-2229, 2004. PMID: 15004230. DOI: $10.1091 / \mathrm{mbc} . \mathrm{e} 03-10-0777$

96 Reed SE, Hodgson LR, Song S, May MT, Kelly EE, McCaffrey MW, Mastick CC, Verkade P and Tavaré JM: A role for Rab14 in the endocytic trafficking of GLUT4 in 3T3-L1 adipocytes. J Cell Sci 126(Pt 9): 1931-1941, 2013. PMID: 23444368. DOI: $10.1242 /$ jcs. 104307

97 Zhao FQ and Keating AF: Functional properties and genomics of glucose transporters. Curr Genomics 8(2): 113-128, 2007. PMID: 18660845. DOI: 10.2174/138920207780368187

98 Wood IS and Trayhurn P: Glucose transporters (GLUT and SGLT): expanded families of sugar transport proteins. Br J Nutr 89(1): 3-9, 2003. PMID: 12568659. DOI: 10.1079/BJN2002763

99 Henriksen EJ: Invited review: Effects of acute exercise and exercise training on insulin resistance. J Appl Physiol (1985) 93(2): 788-796, 2002. PMID: 12133893. DOI: 10.1152/japplphysiol.01219.2001

100 Brewer PD, Habtemichael EN, Romenskaia I, Coster AC and Mastick CC: Rab14 limits the sorting of Glut4 from endosomes into insulin-sensitive regulated secretory compartments in adipocytes. Biochem J 473(10): 1315-1327, 2016. PMID: 26936971. DOI: $10.1042 / B C J 20160020$
Received July 21, 2021

Revised December 9, 2021

Accepted January 7, 2022 